\title{
On the effectiveness of nitrogen oxide reductions as a control over ammonium nitrate aerosol
}

\author{
S. E. Pusede ${ }^{1, a}$, K. C. Duffey ${ }^{1}$, A. A. Shusterman ${ }^{1}$, A. Saleh ${ }^{1}$, J. L. Laughner ${ }^{1}$, P. J. Wooldridge ${ }^{1}$, Q. Zhang ${ }^{2}$, \\ C. L. Parworth ${ }^{2}$, H. Kim ${ }^{3}$, S. L. Capps ${ }^{4}$, L. C. Valin ${ }^{5}$, C. D. Cappa ${ }^{6}$, A. Fried ${ }^{7}$, J. Walega ${ }^{7}$, J. B. Nowak ${ }^{8}$, \\ A. J. Weinheimer ${ }^{9}$, R. M. Hoff ${ }^{10}$, T. A. Berkoff ${ }^{11}$, A. J. Beyersdorf ${ }^{11}$, J. Olson ${ }^{11}$, J. H. Crawford ${ }^{11}$, and R. C. Cohen ${ }^{1,12}$ \\ ${ }^{1}$ Department of Chemistry, University of California Berkeley, Berkeley, CA 94720, USA \\ ${ }^{2}$ Department of Environmental Toxicology, University of California at Davis, Davis, CA 95616, USA \\ ${ }^{3}$ Center for Environment, Health and Welfare Research, Korea Institute of Science and Technology, Seoul, Korea \\ ${ }^{4}$ Department of Mechanical Engineering, University of Colorado Boulder, Boulder, CO 80309, USA \\ ${ }^{5}$ Lamont-Doherty Earth Observatory, Columbia University, Palisades, NY 10964, USA \\ ${ }^{6}$ Department of Civil and Environmental Engineering, University of California at Davis, Davis, CA 95616, USA \\ ${ }^{7}$ Institute of Arctic and Alpine Research, University of Colorado, Boulder, CO 80309, USA \\ ${ }^{8}$ Aerodyne Research, Inc., Billerica, Billerica, MA 01821, USA \\ ${ }^{9}$ Atmospheric Chemistry Division, National Center for Atmospheric Research, Boulder, CO 80307, USA \\ ${ }^{10}$ Department of Physics, University of Maryland Baltimore County, Baltimore, MD 21250, USA \\ ${ }^{11}$ NASA Langley Research Center, Hampton, VA 23681, USA \\ ${ }^{12}$ Department of Earth and Planetary Science, University of California Berkeley, Berkeley, CA 94720, USA \\ ${ }^{a}$ now at: Department of Environmental Sciences, University of Virginia, Charlottesville, VA 22904, USA
}

Correspondence to: Ronald C. Cohen (rccohen@berkeley.edu)

Received: 23 August 2015 - Published in Atmos. Chem. Phys. Discuss.: 7 October 2015

Revised: 17 February 2016 - Accepted: 18 February 2016 - Published: 2 March 2016

\begin{abstract}
Nitrogen oxides $\left(\mathrm{NO}_{x}\right)$ have fallen steadily across the US over the last 15 years. At the same time, $\mathrm{NO}_{x}$ concentrations decrease on weekends relative to weekdays, largely without co-occurring changes in other gas-phase emissions, due to patterns of diesel truck activities. These trends taken together provide two independent constraints on the role of $\mathrm{NO}_{x}$ in the nonlinear chemistry of atmospheric oxidation. In this context, we interpret interannual trends in wintertime ammonium nitrate $\left(\mathrm{NH}_{4} \mathrm{NO}_{3}\right)$ in the San Joaquin Valley of California, a location with the worst aerosol pollution in the US and where a large portion of aerosol mass is $\mathrm{NH}_{4} \mathrm{NO}_{3}$. Here, we show that $\mathrm{NO}_{x}$ reductions have simultaneously decreased nighttime and increased daytime $\mathrm{NH}_{4} \mathrm{NO}_{3}$ production over the last decade. We find a substantial decrease in $\mathrm{NH}_{4} \mathrm{NO}_{3}$ since 2000 and conclude that this decrease is due to reduced nitrate radical-initiated production at night in residual layers that are decoupled from fresh emissions at the surface. Further reductions in $\mathrm{NO}_{x}$ are imminent in California, and nationwide, and we make a quantitative prediction of the
\end{abstract}

response of $\mathrm{NH}_{4} \mathrm{NO}_{3}$. We show that the combination of rapid chemical production and efficient $\mathrm{NH}_{4} \mathrm{NO}_{3}$ loss via deposition of gas-phase nitric acid implies that high aerosol days in cities in the San Joaquin Valley air basin are responsive to local changes in $\mathrm{NO}_{x}$ within those individual cities. Our calculations indicate that large decreases in $\mathrm{NO}_{x}$ in the future will not only lower wintertime $\mathrm{NH}_{4} \mathrm{NO}_{3}$ concentrations but also cause a transition in the dominant $\mathrm{NH}_{4} \mathrm{NO}_{3}$ source from nighttime to daytime chemistry.

\section{Introduction}

Aerosol abundances are decreasing across the US, improving air quality and affecting climate. These decreases have been broadly attributed to regulatory controls on the emissions of gas-phase precursors; however, it has proven difficult to link precursor reductions to observed changes in aerosol concen- 

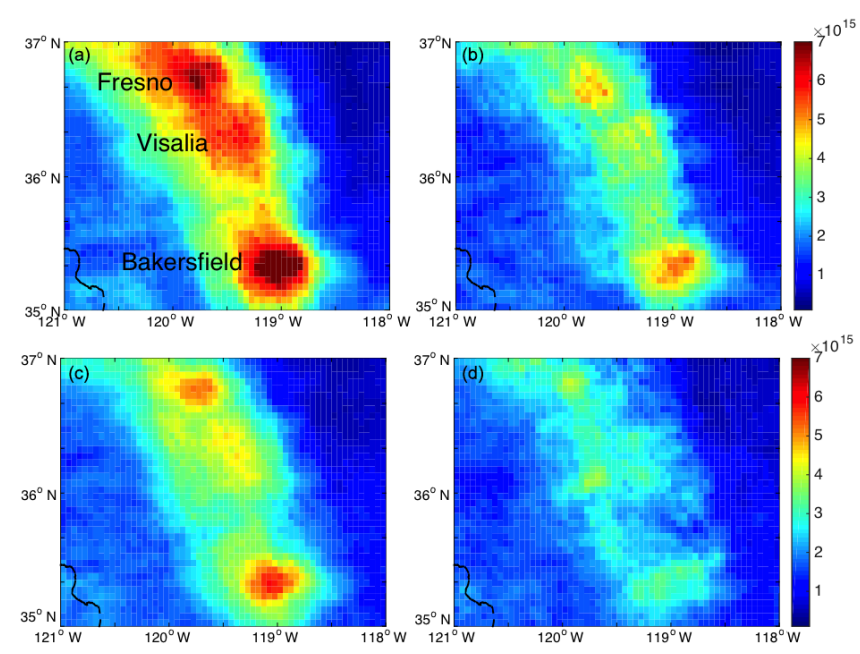

Figure 1. Wintertime (November-March) $\mathrm{NO}_{2}$ columns (molecules $\mathrm{cm}^{-2}$ ) in the SJV using the UC Berkeley OMI BEHR retrieval (Russell et al., 2011). The urban $\mathrm{NO}_{2}$ plumes of Fresno, Visalia, and Bakersfield are labeled to the left of their respective cities in panel (a). Panel (a) shows 2005-2006 weekdays (Tuesday-Friday). Panel (b) shows 2005-2006 weekends (Saturday-Sunday). Panel (c) shows 2012-2013 weekdays. Panel (d) shows 2012-2013 weekends.

tration via specific chemical mechanisms. Thus, there is limited knowledge of how impacts will scale in the future.

We present an analysis to identify driving chemical mechanisms and to quantify the effects of large reductions in nitrogen oxides $\left(\mathrm{NO}_{x}\right)$ (e.g., Russell et al., 2012; McDonald et al., 2012) on secondary aerosol chemistry. We take advantage of decreased $\mathrm{NO}_{x}$ emissions on weekends compared to weekdays, which occur mostly without changes in other gas-phase emissions (e.g., Dallmann et al., 2012), and couple these weekday-weekend patterns to long-term $\mathrm{NO}_{x}$ reductions (Pusede and Cohen, 2012). The effect is that weekday $\mathrm{NO}_{x}$ levels equal weekend $\mathrm{NO}_{x}$ years earlier in the record (Fig. 1). We use this $\mathrm{NO}_{x}$ constraint to interpret trends in observed wintertime ammonium nitrate $\left(\mathrm{NH}_{4} \mathrm{NO}_{3}\right)$ concentrations over the last decade in the San Joaquin Valley (SJV) of California.

The SJV experiences the most severe aerosol pollution in the US (American Lung Association, 2014). From 2001 to 2013 there were on average 44 exceedances each winter (November-March) of the $24 \mathrm{~h}$ National Ambient Air Quality Standard (NAAQS) of $35 \mu \mathrm{g} \mathrm{m}^{-3}$ in the cities of Bakersfield and Fresno, with as many as 70 per winter early in the record. High aerosol in the SJV is generally limited to the winter months, with few exceedances occurring in other seasons. In the SJV, 30-80\% of wintertime aerosol mass is $\mathrm{NH}_{4} \mathrm{NO}_{3}$ and the remaining portion is mostly organic material (Chow et al., 2006; Chen et al., 2007; Ge et al., 2012). Characteristics of the wintertime SJV that are conducive to high aerosol abundances include shallow bound- ary layers (Bianco et al., 2011); prolonged periods of stagnation (Smith et al., 1981); and large emissions of $\mathrm{NO}_{x}$ $\left(\mathrm{NO}_{x} \equiv \mathrm{NO}+\mathrm{NO}_{2}\right)$, ammonia $\left(\mathrm{NH}_{3}\right)$ (Goebes et al., 2003; Clarisse et al., 2010), and organic aerosol (Ge et al., 2012). These conditions pose challenges to accurately simulating secondary aerosol in the region, as models need to represent bidirectional $\mathrm{NH}_{3}$ exchange (Gilliland et al., 2006; Flechard et al., 2010; Pleim et al., 2013), variable local meteorology, complex airflows, and vertical stratification in the rates of $\mathrm{NO}_{2}$ oxidation to $\mathrm{NO}_{3}^{-}$(Heald et al., 2012; Walker et al., 2012; Kelly et al., 2014; Schiferl et al., 2014; Markovic et al., 2014).

In this paper, we take an observational approach, combining the decade-long record of speciated aerosol concentrations and of gas-phase precursors in the region with detailed measurements collected during the DISCOVER-AQ experiment (Deriving Information on Surface Conditions from COlumn and VERtically resolved observations relevant to Air Quality, 14 January-14 February 2013). We show that wintertime $\mathrm{NO}_{3}^{-}$, which we treat as a measured surrogate for $\mathrm{NH}_{4} \mathrm{NO}_{3}$, has been dependent only on the $\mathrm{NO}_{2}$ concentration over the last 12 years. We calculate observationally constrained nighttime and photochemical $\mathrm{NO}_{3}^{-}$production rates and show that measured trends in wintertime $\mathrm{NO}_{3}^{-}$can be explained by decreased nitrate radical-initiated production in nocturnal residual layers, which are unmonitored layers of the atmosphere that are effectively separated from surface emissions at night. We test the impacts of forthcoming $\mathrm{NO}_{x}$ emission controls on the probability of future NAAQS exceedances, showing that $\mathrm{NO}_{x}$ reductions will not only decrease the frequency of high aerosol days but also shift both the timing and the oxidation mechanisms that drive $\mathrm{NH}_{4} \mathrm{NO}_{3}$ production.

\section{Results from observations}

Trends in wintertime (November-March) $24 \mathrm{~h} \mathrm{NO}_{3}^{-}$versus daytime (10:00-15:00 local time) $\mathrm{NO}_{2}$ are shown in Fig. 2 in the cities Fresno and Bakersfield on weekdays and weekends for the period 2001-2013. The source of these observations, the methods used for collection, and measurement biases are discussed in Appendix A. Weekdays are defined as Tuesday-Friday and weekends are Saturday-Sunday. We expect carryover to have an effect on the interpretation, as concentrations of $\mathrm{NO}_{2}$ and aerosol are not only influenced by present day processes but also have some memory of processes occurring on the preceding day, especially in the winter when surface winds are slow and disorganized and horizontal transport is weak. We exclude Monday from weekdays for this reason but retain Saturdays to improve weekend statistics. As a result, weekend medians reported here might be slightly higher than would be observed due to weekend emissions alone. We define the day as beginning and ending at sunrise, since nighttime $\mathrm{NO}_{3}^{-}$production builds from reac- 

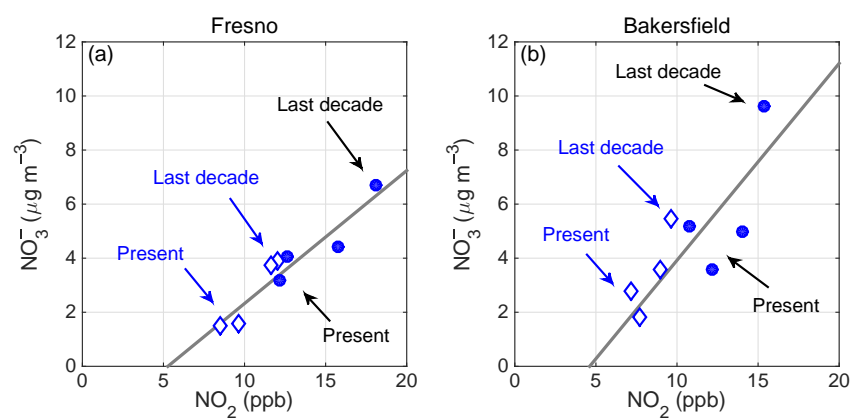

Figure 2. Observed $\mathrm{NO}_{3}^{-}\left(\mu \mathrm{g} \mathrm{m}^{-3}\right)$ in $\mathrm{PM}_{10}$ versus daytime (10:00-15:00 LT) $\mathrm{NO}_{2}$ on weekdays (closed circles) and weekends (open diamonds). Data are 3-year medians of wintertime (November-March) data in Fresno (a) (2001-2012) and Bakersfield (b) (2001-2013). There are an average of 41 weekday days and 18 weekend days point ${ }^{-1}$. Uncertainties in $\mathrm{NO}_{3}^{-}$are $\pm_{20}^{32} \% \mathrm{\mu g} \mathrm{m}^{-3}$ on weekdays and $\pm_{30}^{40} \% \mu \mathrm{g} \mathrm{m}^{-3}$ on weekends for $\mathrm{NO}_{3}^{-}$and less than $\pm 9 \%$ on weekdays and $\pm 13 \%$ on weekends for $\mathrm{NO}_{2}$ (see text for details). Slopes are $0.5 \mu \mathrm{g} \mathrm{m}^{-3} \mathrm{NO}_{3}^{-} \mathrm{ppb}^{-1} \mathrm{NO}_{2}$ in Fresno and $0.64 \mu \mathrm{g} \mathrm{m}^{-3} \mathrm{NO}_{3}^{-} \mathrm{ppb}^{-1} \mathrm{NO}_{2}$ in Bakersfield and are calculated using a weighted linear least squares fit with errors assumed in both the $x$ and $y$; weights are computed as counting errors derived from the number of observations.

tants present in the atmosphere during the preceding daytime hours.

In the wintertime SJV, persistent stagnant conditions are common and punctuated only by infrequent cold fronts accompanied by strong winds that remove accumulated pollution from the basin. Stagnation events are a few days to multiple weeks in duration, and, during these stable periods, surface winds are slow and disorganized, controlled largely by surface heating, with limited horizontal mixing (Smith et al., 1981). On any individual winter day, air stagnation and planetary boundary layer height are the dominant controls over gas and aerosol concentrations; however, considering the data separately by weekday and weekend and then comparing year-to-year changes instead draws attention to the effects of emissions and subsequent chemistry.

By this method, the $\mathrm{NO}_{3}^{-}$mass concentration is observed to have depended on the previous day's daytime $\mathrm{NO}_{2}$ concentration with a sensitivity of $0.5 \mu \mathrm{g} \mathrm{m}^{-3} \mathrm{ppb}^{-1} \mathrm{NO}_{2}$ in Fresno and $0.64 \mu \mathrm{g} \mathrm{m}^{-3} \mathrm{ppb}^{-1} \mathrm{NO}_{2}$ in Bakersfield (slopes in Fig. 2). Uncertainties in the $\mathrm{NO}_{3}^{-}$concentration are computed as counting errors, with $N$ as the total number of wintertime data points (3-year average), and are $\pm 20 \%$ on weekdays and $\pm 30 \%$ on weekends. Errors in $\mathrm{NO}_{2}$ are computed in the same way and are less than $\pm 9 \%$ on weekdays and $\pm 13 \%$ on weekends in both Fresno and Bakersfield. We interpret the positive $x$ intercept in Fig. 2 as consistent with the known low bias in $\mathrm{NO}_{3}^{-}$measurements (Appendix A) and the shorter wintertime atmospheric lifetime of $\mathrm{NO}_{3}^{-}$than $\mathrm{NO}_{2}$ (Sect. 4). Uncertainty estimates, including a low $\mathrm{NO}_{3}^{-}$ measurement bias of $25 \%$, are $\pm_{20}^{32} \% \mu \mathrm{g} \mathrm{m}^{-3} \mathrm{ppb}^{-1} \mathrm{NO}_{2}$ on weekdays and $\pm_{30}^{40} \% \mu \mathrm{g} \mathrm{m}^{-3} \mathrm{ppb}^{-1} \mathrm{NO}_{2}$ on weekends. One ppb $\mathrm{NO}_{2}$ corresponds to $2.56 \mu \mathrm{g} \mathrm{m}^{-3} \mathrm{NO}_{3}^{-}$after oxidation (at $25^{\circ} \mathrm{C}$ and $1 \mathrm{~atm}$ ); thus the observed correlation corresponds to a decrease in $\mathrm{NO}_{3}^{-}$mass that is $20 \%$ of the $\mathrm{NO}_{2}$ decrease. While the full budget for wintertime $\mathrm{NO}_{x}$ loss is beyond the scope of this paper, Fig. 2 implies that on average in the wintertime, $20 \%$ of each day's $\mathrm{NO}_{x}$ emissions are converted to $\mathrm{NO}_{3}^{-}$in 1-2 days.

The key idea is that present-day $\mathrm{NO}_{3}^{-}$concentrations on weekdays are equal to what were seen on weekends a decade ago, i.e., the $\mathrm{NO}_{2}$ dependence of $\mathrm{NO}_{3}^{-}$has been unchanged with time. This suggests that in the wintertime average, the only source of $\mathrm{NO}_{3}^{-}$in the atmosphere has been oxidation of $\mathrm{NO}_{2}$ and that $\mathrm{NH}_{4} \mathrm{NO}_{3}$ production has been nitrate rather than ammonium limited. Agreement of $\mathrm{NO}_{3}^{-}$in different years at identical $\mathrm{NO}_{2}$ implies that there has been little change over time in the chemical mechanism producing $\mathrm{NO}_{3}^{-}$ and hence $\mathrm{NH}_{4} \mathrm{NO}_{3}$.

Additional evidence comes from observations made during DISCOVER-AQ, in which the sum of gas-phase nitric acid and aerosol-phase $\mathrm{NO}_{3}^{-}\left(\mathrm{NO}_{3}^{-}(\mathrm{g}+\mathrm{p})\right.$ was measured onboard the NASA P-3B on six research flights with almost identical flight patterns (Fig. 3a). See Appendix A for a description of the $\mathrm{NO}_{3}^{-}(\mathrm{g}+\mathrm{p})$ measurements and DISCOVER-AQ experiment. Comparing the spatial distribution of $\mathrm{NO}_{3}^{-}(\mathrm{g}+\mathrm{p})$ within the fully developed (afternoon) boundary layer (see Appendix A for the boundary layer filtering procedure) to $\mathrm{NO}_{2}$ observed from the satellite (Fig. 1) and $\mathrm{NO}_{x}$ from onboard the P3-B (Fig. 3b) suggests that $\mathrm{NO}_{3}^{-}(\mathrm{g}+\mathrm{p})$ better follows spatial patterns in $\mathrm{NO}_{2}$ than gasphase $\mathrm{NH}_{3}$ (Fig. 3c), the precursor of particulate-phase $\mathrm{NH}_{4}^{+}$.

In Fig. 3a, urban-rural gradients in $\mathrm{NO}_{3}^{-}(\mathrm{g}+\mathrm{p})$ are steep. In Bakersfield, $\mathrm{NO}_{3}^{-}(\mathrm{g}+\mathrm{p})$ was on average $18-20 \mu \mathrm{g} \mathrm{m}^{-3}$ near the city center, twice as high as just $20 \mathrm{~km}$ to the northeast. During DISCOVER-AQ, surface wind speeds were $\sim 2$ $3 \mathrm{~m} \mathrm{~s}^{-1}$ in the daytime (10:00-15:00 LT), $\sim 1-2 \mathrm{~m} \mathrm{~s}^{-1}$ in the morning (06:00-10:00 LT), and typically $<1 \mathrm{~m} \mathrm{~s}^{-1}$ at night. An air parcel moving within the surface layer at $3 \mathrm{~m} \mathrm{~s}^{-1}$ would require approximately $\sim 20$ daytime $\mathrm{h}$, equivalent to multiple days, to either reach Fresno from the upwind cities of Stockton or San Jose or to reach Bakersfield from Fresno. An additional transport mechanism is mixing by winds in nocturnal low-level jets, which are well documented in the SJV in the summertime (Bao et al., 2008). There are few measurements of these winds in the winter, but wind speeds of up to $1-8 \mathrm{~m} \mathrm{~s}^{-1}$ have been observed at $0.1-2 \mathrm{~km}$ a.g.l. (3 days of data), which are fast enough to mix species valley wide in 1-2 days (Chow et al., 2006). However, the measured spatial heterogeneity in $\mathrm{NO}_{3}^{-}(\mathrm{g}+\mathrm{p})$ (Fig. 3a) indicates faster and/or more localized processes control a significant portion of the $\mathrm{NO}_{3}^{-}$concentration in each city. 

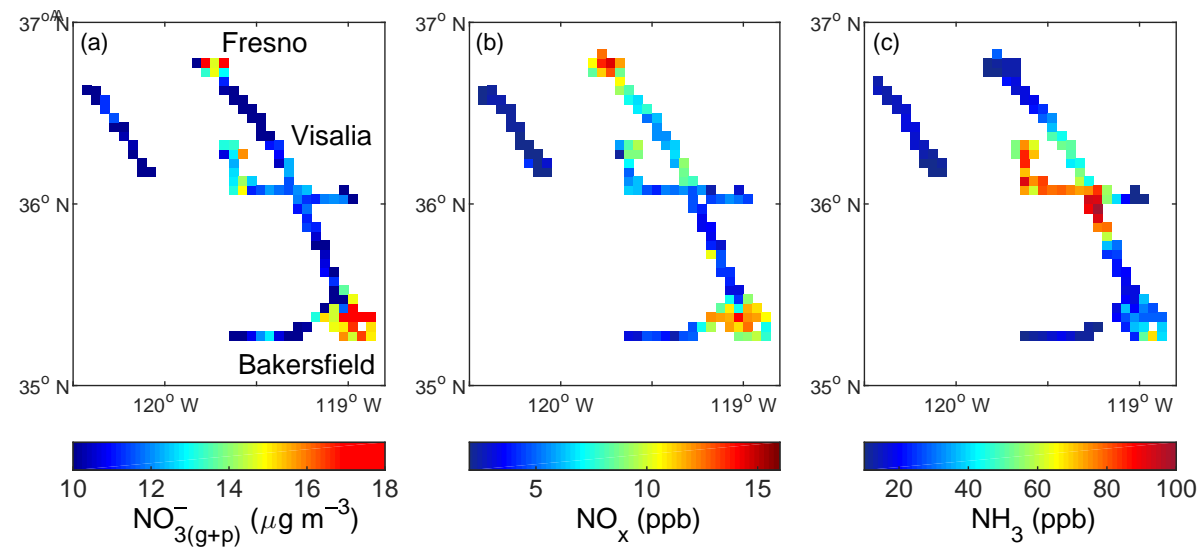

Figure 3. $\mathrm{NO}_{3}^{-}(\mathrm{g}+\mathrm{p})\left(\mu \mathrm{g} \mathrm{m}^{-3}\right)$ in $\mathrm{PM}_{2.5}(\mathbf{a}), \mathrm{NO}_{x}(\mathrm{ppb})(\mathbf{b})$, and $\mathrm{NH}_{3}(\mathrm{ppb})$ (c) measured onboard the NASA P-3B below the fully formed afternoon boundary layer and at pressure altitude (a.s.l.) greater than 0 on the same days and averaged to a $0.05^{\circ} \times 0.05^{\circ}$ grid.

We infer from Figs. 2 and 3 that the oxidation of locally emitted $\mathrm{NO}_{x}$ is the largest term affecting the production of $\mathrm{NH}_{4} \mathrm{NO}_{3}$, that $\mathrm{NH}_{3}$ is in excess, and that transport and mixing are too slow to fully homogenize the aerosol throughout the wintertime SJV.

\section{Chemistry in the dynamic near-surface atmosphere}

Under the abundant $\mathrm{NH}_{3}$, low sulfur dioxide, high aerosol, and low temperature conditions found in the wintertime SJV, most $\mathrm{NO}_{3}^{-}$is aerosol bound in the $24 \mathrm{~h}$ average and $\mathrm{NH}_{4} \mathrm{NO}_{3}$ abundances are driven by $\mathrm{NO}_{3}^{-}$production $\left(\mathrm{PNO}_{3}^{-}\right)$. $\mathrm{PNO}_{3}^{-}$ occurs by distinct nighttime and daytime mechanisms, each of which is a nonlinear function of $\mathrm{NO}_{2}$.

Nitrate radical $\left(\mathrm{NO}_{3}\right)$ is the most important nighttime oxidant (Brown and Stutz, 2012). It is formed via reaction of $\mathrm{NO}_{2}$ with $\mathrm{O}_{3}$ (Reaction 1).

$\mathrm{NO}_{2}+\mathrm{O}_{3} \rightarrow \mathrm{NO}_{3}$

$\mathrm{NO}_{3}$-initiated chemistry occurs mainly at night because $\mathrm{NO}_{3}$ photolyzes rapidly to $\mathrm{NO}_{2}$. After sunset, large $\mathrm{NO}$ emissions can titrate $\mathrm{O}_{3}$, altering the relative amounts of $\mathrm{NO}_{2}$ and $\mathrm{O}_{3}$ but conserving odd oxygen $\left(\mathrm{O}_{x} \equiv \mathrm{NO}_{2}+\mathrm{O}_{3}\right)$. $\mathrm{NO}_{3}$ radical production is a nonlinear function of $\mathrm{NO}_{2}$ for a given $\mathrm{O}_{3}$ concentration, increasing with $\mathrm{NO}_{2}$ at low $\mathrm{NO}_{x}$, maximizing when $\mathrm{NO}_{2}$ is equal to $\mathrm{O}_{3}$ at constant $\mathrm{O}_{x}$, and decreasing at higher $\mathrm{NO}_{x}$, shown as $\mathrm{NO}_{2}$ (Appendix B, Fig. B1a).

In the evening, reduced sunlight diminishes the heating of the Earth's surface, leading to strong suppression of vertical mixing and the formation of a shallow nocturnal boundary layer (NBL). Between the NBL and the free troposphere, in the nocturnal residual layer (NRL), mixing is weak and further layering may occur (Brown et al., 2007). The initial concentrations of species in the NRL are determined by the concentrations observed at the point in time when the residual layer decouples from the NBL, around sunset. Af- terwards, the strong surface inversion keeps fresh emissions from entering the NRL, yet vertical chemical gradients have been observed within layers (Brown et al., 2007). The NRL is seen by surface monitors in the morning when solar heating and turbulent mixing reincorporate what was the NRL into the growing daytime boundary layer (Fig. 4), a process that also alters the NRL composition. On nights when $\mathrm{NO}_{3}$ radical production in the NBL is 0 due to high $\mathrm{NO}$ emissions, $\mathrm{NO}_{3}$ chemistry may still be active in the dynamically decoupled NRL. Loss from the atmosphere is likewise affected by this vertical structuring, as deposition to the surface occurs during the daytime and during the night from the NBL but not during the night from the NRL. Figure 5 shows examples of enduring nocturnal structure seen via potential temperature, the vertical distribution of $\mathrm{NO}_{3(\mathrm{~g}+\mathrm{p})}^{-}$, and $\mathrm{O}_{3}$ during DISCOVER-AQ by the P-3B in the early mornings over Bakersfield. At least one NRL is apparent for each profile, evident in the potential temperature variability; however, due to a combination of extremely shallow surface inversions, intermittent $\mathrm{NO}_{3}^{-}(\mathrm{g}+\mathrm{p})$ sampling, and science flight timing, it is unclear that the $\mathrm{P}-3 \mathrm{~B}$ ever captured $\mathrm{NO}_{3}^{-}(\mathrm{g}+\mathrm{p})$ concentrations in the NBL prior to the second flight circuit in the late morning (not shown) when significant atmospheric mixing had already taken place.

Nitrate radical reacts with $\mathrm{NO}_{2}$ to form dinitrogen pentoxide $\left(\mathrm{N}_{2} \mathrm{O}_{5}\right)$ and generally under atmospheric conditions of high $\mathrm{NO}_{2}$ and low temperature, $\mathrm{N}_{2} \mathrm{O}_{5} \gg \mathrm{NO}_{3}$ (Brown et al., 2009; Brown and Stutz, 2012). The lifetime of $\mathrm{N}_{2} \mathrm{O}_{5}$ to thermal decomposition to $\mathrm{NO}_{2}$ and $\mathrm{NO}_{3}$ is $\sim 10 \mathrm{~min}$ at $270 \mathrm{~K}$. $\mathrm{NO}_{3}$ is also lost to reaction with certain organic species, especially compounds with unsaturated carbon-carbon bonds and aldehydes. When reaction times are long, for example during long, dark winter nights and when unsaturated hydrocarbon emissions are low, the most important loss of $\mathrm{NO}_{3}$ is via $\mathrm{N}_{2} \mathrm{O}_{5}$ uptake onto aerosols (e.g., Dentener and Crutzen, 1993; Macintyre and Evans, 2010; Wagner et al., 2013), 


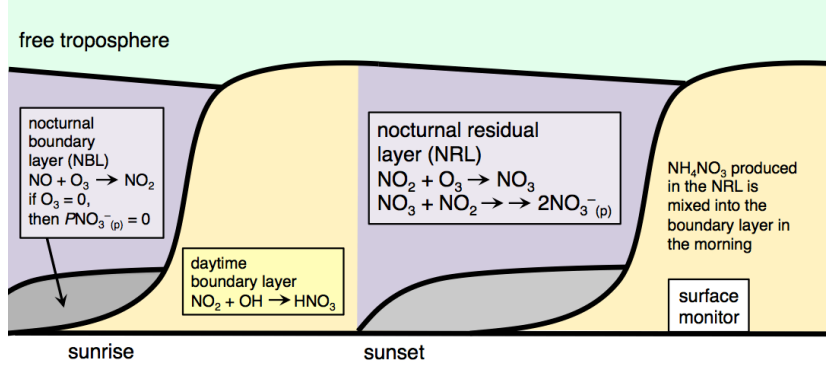

Figure 4. Simplified illustration of the diurnal evolution of the nearsurface atmosphere as it relates to $\mathrm{PNO}_{3}^{-}$. Boundary layer dynamics schematic adapted from Stull (1988).

whereupon $\mathrm{N}_{2} \mathrm{O}_{5}$ reacts with aerosol-phase water to give either two $\mathrm{NO}_{3}^{-}$or, if $\mathrm{NO}_{2}^{+}$combines with $\mathrm{Cl}^{-}, \mathrm{ClNO}_{2}+\mathrm{NO}_{3}^{-}$. At sunrise, $\mathrm{ClNO}_{2}$ photolyzes within a few hours (Nelson and Johnston, 1981), releasing $\mathrm{NO}_{2}$ and $\mathrm{Cl}$ radical, the latter reacting rapidly with most gas-phase organic compounds. The heterogeneous loss rate of $\mathrm{N}_{2} \mathrm{O}_{5}$ is a function of the total aerosol surface area and of the fraction of gas-particle collisions resulting in $\mathrm{N}_{2} \mathrm{O}_{5}$ uptake. The latter is aerosol composition dependent, enhanced at higher aerosol water content (e.g., Hu and Abbatt, 1997; Hallquist et al., 2003; Thornton et al., 2003), reduced in the presence of organic coatings (e.g., Cosman and Bertram, 2008; McNeill et al., 2006), and inversely proportional to $\mathrm{NO}_{3}^{-}$(e.g., Wahner et al., 1998; Hallquist et al., 2003; Bertram and Thornton, 2009; Wagner et al., 2013).

During the daytime, nitric acid $\left(\mathrm{HNO}_{3}\right)$ is the gas-phase reaction product of the oxidation of $\mathrm{NO}_{2}$ and the hydroxyl radical $(\mathrm{OH})$ (Reaction 2).

$\mathrm{NO}_{2}+\mathrm{OH}+M \rightarrow \mathrm{HNO}_{3}+M$

The production rate of $\mathrm{HNO}_{3}$ increases rapidly with increasing $\mathrm{NO}_{x}$ at low $\mathrm{NO}_{x}$ and converges at a limit set by the primary $\mathrm{HO}_{x}\left(\mathrm{HO}_{x} \equiv \mathrm{OH}+\mathrm{HO}_{2}+\mathrm{RO}_{2}\right)$ production rate at higher $\mathrm{NO}_{x}$. Major sources of $\mathrm{HO}_{x}$ in the polluted troposphere are $\mathrm{O}\left({ }^{1} \mathrm{D}\right)+\mathrm{H}_{2} \mathrm{O}$, formaldehyde $\left(\mathrm{CH}_{2} \mathrm{O}\right)$, and nitrous acid (HONO). The functional form of the dependence of $\mathrm{HNO}_{3}$ production on $\mathrm{NO}_{2}$ (Fig. B1b) arises from the nonlinear effects of $\mathrm{NO}_{x}$ on the $\mathrm{OH}$ abundance, as $\mathrm{NO}_{x}$ both propagates and terminates the $\mathrm{HO}_{x}$ catalytic cycle. Under the high $\mathrm{NO}_{x}$ conditions of the wintertime $\mathrm{SJV}, \mathrm{HNO}_{3}$ is the dominant daytime $\mathrm{HO}_{x}$ termination product. Combined with excess $\mathrm{NH}_{3}$, partitioning to the aerosol phase is a function of ambient temperature and humidity.

Trends in calculated wintertime $\mathrm{PNO}_{3}^{-}$for the nighttime and daytime mechanisms, as constrained by the observations (calculations and data are described in Appendix B), suggest that $\mathrm{PNO}_{3}^{-}$in the NRL is the largest source of chemistry that matches trends in $\mathrm{NO}_{3}^{-}$(Fig. 2). Specifically, $\mathrm{PNO}_{3}^{-}$in the NRL exhibits identical $\mathrm{NO}_{2}$ dependence as observed in the $\mathrm{NO}_{3}^{-}$measurements - both over time and from weekday to weekend. In Fig. 6, the calculated annual wintertime daily-integrated $\mathrm{PNO}_{3}^{-}$in the NRL is shown versus daytime $\mathrm{NO}_{2}$ on weekdays and weekends in Fresno and Bakersfield. $\mathrm{PNO}_{3}^{-}$in the NRL has decreased by $0.9 \mu \mathrm{g} \mathrm{m}^{-3} \mathrm{day}^{-1} \mathrm{ppb}^{-1} \mathrm{NO}_{2}$ in both cities, a rate approximately twice the trend observed in $\mathrm{NO}_{3}^{-}$versus $\mathrm{NO}_{2}$. The total daytime $\mathrm{PNO}_{3}^{-}$(Reaction R2), equal to the sum of $\mathrm{PNO}_{3}^{-}$attributed to the $\mathrm{HO}_{x}$ sources, $\mathrm{O}\left({ }^{1} \mathrm{D}\right)+\mathrm{H}_{2} \mathrm{O}$, $\mathrm{HONO}$, and $\mathrm{CH}_{2} \mathrm{O}$, has, by contrast, not significantly changed as a function of $\mathrm{NO}_{2}$ over the last decade. In fact, $\mathrm{PNO}_{3}^{-}$linked to the $\mathrm{HO}_{x}$ sources $\mathrm{O}\left({ }^{1} \mathrm{D}\right)+\mathrm{H}_{2} \mathrm{O}$ and $\mathrm{CH}_{2} \mathrm{O}$ has increased by $\sim 5 \%$ since 2001 . $\mathrm{PNO}_{3}^{-}$attributed to $\mathrm{HONO}$ has decreased since 2001 (Appendix B, Fig. B2), displaying comparable $\mathrm{NO}_{2}$ dependence to both measured $\mathrm{NO}_{3}^{-}$concentrations (Fig. 2) and calculated $\mathrm{PNO}_{3}^{-}$in the NRL (Fig. 6). However, we calculate that $P_{N_{3}^{-}}^{-}$in the NRL is approximately 5 times greater than $\mathrm{PNO}_{3}^{-}$formed during the daytime from $\mathrm{OH}$ originating from $\mathrm{HONO}$. In the NBL (not shown) $P_{N^{-}}^{-}$has increased from $<1$ to $3-5 \mu \mathrm{g} \mathrm{m}^{-3}$ day $^{-1}$ on weekdays and to $6-8 \mu \mathrm{g} \mathrm{m}^{-3}$ day $^{-1}$ on weekends due to reduced $\mathrm{NO}_{x}$ titration of $\mathrm{O}_{3}$ at sunset. Increases in NBL $\mathrm{PNO}_{3}^{-}$are not reflected in Fig. 2, potentially because these changes have occurred within a small faction of the volume of the NRL and daytime boundary layer and because depositional loss from the NBL is not impeded. For example, for an NBL that is $10 \%$ the NRL height, $P \mathrm{NO}_{3}^{-}$in the NBL would need to exceed 3 times the NRL production in order to alter the daytime boundary layer concentration by $20 \%$, even if zero deposition is assumed.

\section{Discussion}

\subsection{Relating concentration and $\mathrm{PNO}_{3}^{-}$}

The concentration of $\mathrm{NO}_{3}^{-}(\mathrm{g}+\mathrm{p})$ is a function of $\mathrm{PNO}_{3}^{-}$, as well as loss and mixing. While high aerosol days in the SJV are in part attributed to persistent and severe stagnation, controls over the portion of aerosol mass that is $\mathrm{NH}_{4} \mathrm{NO}_{3}$ are more dynamic (e.g., Pandis and Seinfeld, 1990; Vayenas et al., 2005). In this section we show that the effects of loss and mixing on the $\mathrm{NO}_{3}^{-}$concentration are consistent with observed $\mathrm{NO}_{3}^{-}$trends over time, differences by day-of-week, accumulation rates during stagnation, and differences between Fresno and Bakersfield.

On days when $\mathrm{NH}_{4} \mathrm{NO}_{3}$ exceeded $20-30 \mu \mathrm{g} \mathrm{m}^{-3}$, typical during stagnation periods, the diurnal variability of surface $\mathrm{NO}_{3}^{-}$was characterized by a steep and substantial increase in $\mathrm{NO}_{3}^{-}$in the morning, a slow decline through midday, and a rapid decrease in the afternoon (Fig. 7). On these mornings, the rise rate of $\mathrm{NO}_{3}^{-}$was consistent with two $\mathrm{PNO}_{3}^{-}$ pathways: reincorporation of high- $\mathrm{NO}_{3}^{-} \mathrm{NRL}$ air into the boundary layer and $\mathrm{NO}_{3}^{-}$formed by daytime chemistry with $\mathrm{HONO}$ as the $\mathrm{OH}$ source. By contrast, $\mathrm{OH}$-initiated produc- 


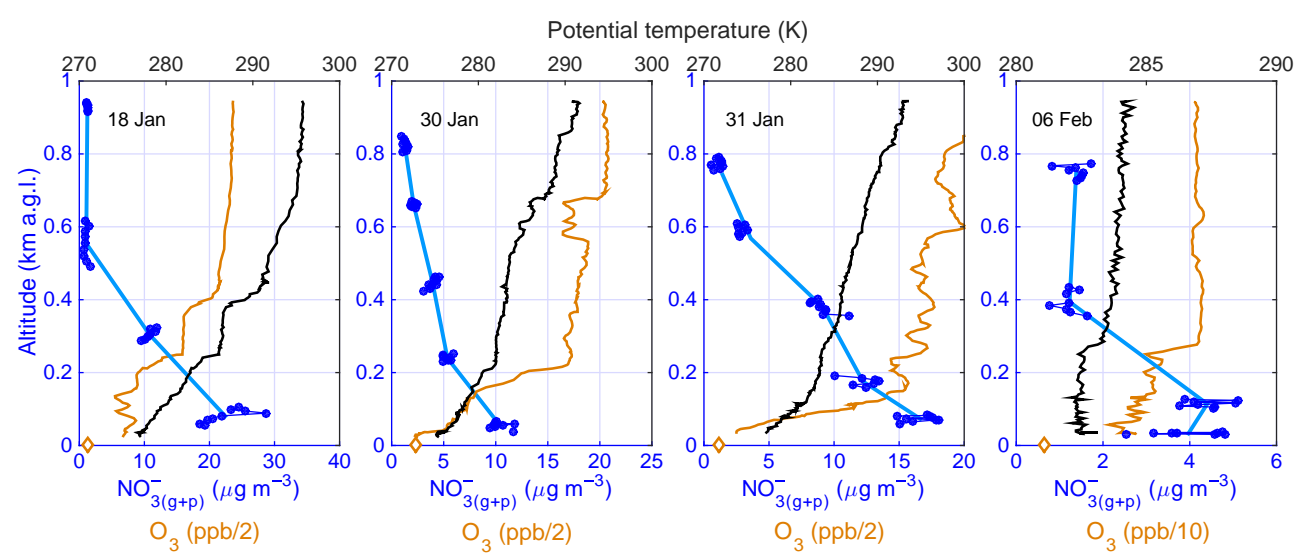

Figure 5. Vertical profiles of $\mathrm{NO}_{3}^{-}(\mathrm{g}+\mathrm{p})\left(\mu \mathrm{g} \mathrm{m}^{-3}\right)$ in $\mathrm{PM}_{2.5}$ between 08:00 and 09:00 LT over the city of Bakersfield on four flights when visibility and air traffic permitted a missed approach. Altitude data are in units km a.g.l. The $\mathrm{O}_{3}$ (orange) and potential temperature (black) are also shown. The orange diamonds represent the mean $\mathrm{O}_{3}$ measured at the surface (08:00-09:00 LT).
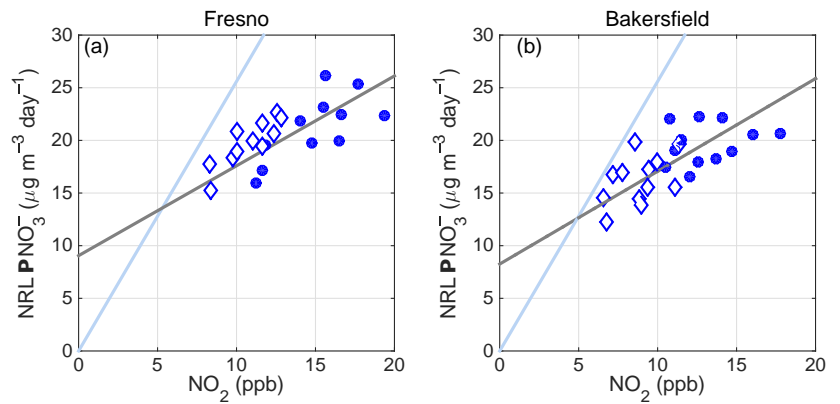

Figure 6. Calculated wintertime median $\mathrm{PNO}_{3}^{-}\left(\mu \mathrm{g} \mathrm{m}^{-3}\right.$ day $\left.{ }^{-1}\right)$ in the NRL versus daytime (10:00-15:00 LT) $\mathrm{NO}_{2}$ (ppb) in Fresno (a) and in Bakersfield (b). Calculations are shown separately for weekdays (closed circles) and weekends (open diamonds). Fresno and Bakersfield results include years 2001-2012 and 2001-2013, respectively. There was no significant difference between medians and means. The light blue line has a slope of 2.56, expected for unit conversion of $\mathrm{NO}_{2}$ to $\mathrm{NO}_{3}^{-}$( $\mathrm{ppb}$ to $\mu \mathrm{g} \mathrm{m}^{-3}$ ). The actual $\mathrm{NO}_{3}^{-}$versus $\mathrm{NO}_{2}$ slope (gray line) is calculated using a weighted linear least squares fit with errors assumed in both the $x$ and $y$ and weights that are the counting errors derived from the number of observations. The direction of time can be inferred from the $\mathrm{NO}_{2}$ trends, as $\mathrm{NO}_{2}$ concentrations have generally decreased each year over the decade.

tion attributed to $\mathrm{O}\left({ }^{1} \mathrm{D}\right)+\mathrm{H}_{2} \mathrm{O}$ and $\mathrm{CH}_{2} \mathrm{O}$ increased gradually throughout the day. At midday, $\mathrm{OH}$-initiated $\mathrm{PNO}_{3}^{-}$, atmospheric loss, and mixing by winds all play upon $\left[\mathrm{NO}_{3}^{-}\right]$. In the afternoon, $\mathrm{OH}$-initiated $\mathrm{PNO}_{3}^{-}$was minimal due to attenuated evening radiation. On days exhibiting this pattern, the $\mathrm{NO}_{3}^{-}$concentration was observed to decrease at a rate equal to $3.0 \pm 1.3 \mu \mathrm{g} \mathrm{m}^{-3} \mathrm{~h}^{-1}(1 \sigma)$, with individual rates determined as the slopes of a linear fit through the magenta data and identified as periods of steady decrease at least three hours long. Time windows were allowed to vary and the average window was 13:25-16:05 LT, spanning 10:30-18:30 LT.
We use this afternoon rate of change, which is when loss dominates production and mixing, to derive the atmospheric $\mathrm{NO}_{3}^{-}$lifetime $\left(\tau_{\mathrm{NO}_{3}^{-}}\right)$.

The atmospheric lifetime of aerosol in the boundary layer is determined by wet and dry deposition of aerosol, the wet and dry deposition of gases in equilibrium with aerosol, and mixing to the free troposphere where concentrations are much lower. Wet deposition occurs by interaction with rain, which scavenges aerosol and soluble gases, and leaves the valley relatively clear. Multi-day fog is common in the winter in the SJV (Holets and Swanson, 1981), enhancing $\mathrm{NH}_{4} \mathrm{NO}_{3}$ removal when fog leads to rain or drizzle (Jacob et al., 1986a, b), as inorganic ions readily partition into aqueous fog droplets (Waldman et al., 1982; Munger et al., 1983), but having little effect if fog dissipates. Fog has not been seen to accelerate the conversion of $\mathrm{NO}_{2}$ to $\mathrm{NO}_{3}^{-}$in the $\mathrm{SJV}$ (Jacob et al., 1984).

There are few direct measurements of deposition rates of aerosol, $\mathrm{HNO}_{3}$, and $\mathrm{NH}_{3} . \mathrm{HNO}_{3}$ is theorized to deposit at a transport-limited rate, $\mathrm{NH}_{3}$ exchange is dependent on surface and meteorological conditions, and aerosol, especially smaller particles, to deposit slowly. $\mathrm{PM}_{1}$ to $\mathrm{PM}_{2.5}$ deposition velocities $\left(v_{\mathrm{d}}\right)$ have been reported to be 0.001 to $0.1 \mathrm{~cm} \mathrm{~s}^{-1}$ (Sehmel, 1980; Slinn, 1982; Farmer et al., 2013), too slow to account for the observed afternoon loss rates in Fig. 7. To compute $\mathrm{NO}_{3}^{-}$loss by deposition of gas-phase $\mathrm{HNO}_{3}, \mathrm{HNO}_{3(\mathrm{~g})}$ was modeled with ISORROPIA II (Nenes et al., 1998; Fountoukis and Nenes, 2007) run in forward mode, an approximation that was reasonable because during the wintertime temperatures were low, humidities were high, and $\mathrm{NH}_{3}$ was abundant. ISORROPIA II was initialized as $\left[\mathrm{NO}_{3}^{-}+\mathrm{HNO}_{3}\right]=\left[\mathrm{NO}_{3}^{-}\right]_{\text {AMS }}$ and $\left[\mathrm{NH}_{4}^{+}+\mathrm{NH}_{3}\right]=\left[\mathrm{NH}_{4}^{+}\right]_{\text {AMS }}$. Calculated $\mathrm{HNO}_{3(\mathrm{~g})}$ was added back to $\left[\mathrm{NO}_{3}^{-}+\mathrm{HNO}_{3}\right]$, while $\mathrm{NH}_{3}(\mathrm{~g})$ was added as $1.1 \mathrm{HNO}_{3(\mathrm{~g})}$ (by mole) to ensure $\mathrm{NH}_{3}$ was in excess 

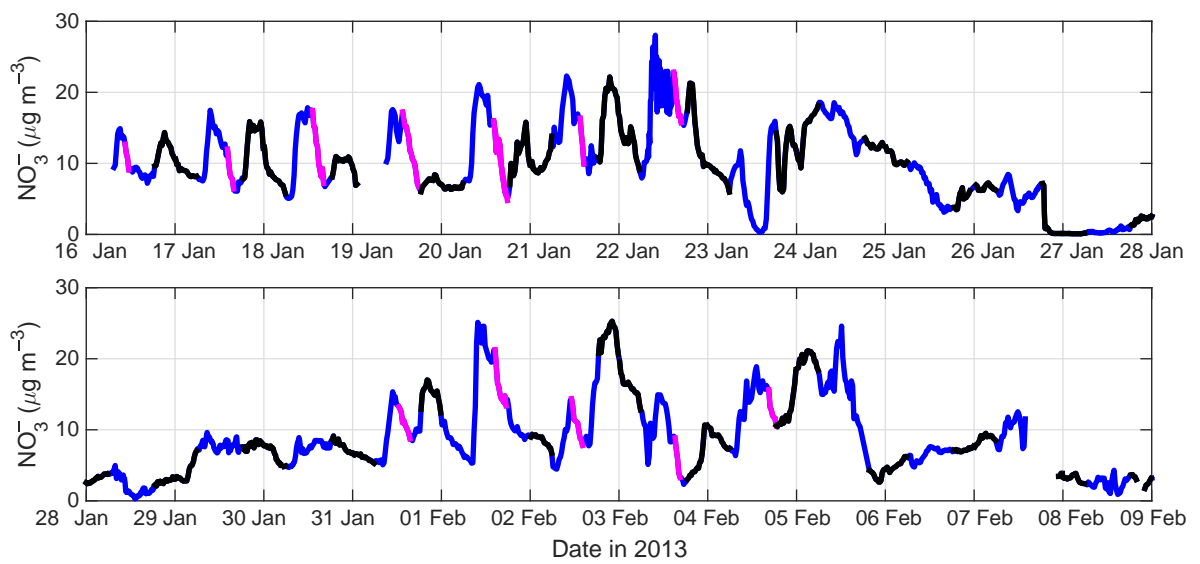

Figure 7. Time series of $\mathrm{NO}_{3}^{-}\left(\mu \mathrm{g} \mathrm{m}^{-3}\right)$ in $\mathrm{PM}_{1}$ measured at the ground in Fresno during DISCOVER-AQ. Days are in blue and nights are in black. Select afternoon data (magenta) were fit to derive $\tau_{\mathrm{NO}_{3}^{-}}$.

because we found $\mathrm{NH}_{4} \mathrm{NO}_{3}$ to be $\mathrm{NO}_{3}^{-}$limited (Figs. 2 and 3). ISORROPIA II was solved iteratively until daytime $\mathrm{HNO}_{3(\mathrm{~g})}$ changed by $<2 \%$ by mass. The phase state was set as metastable (e.g., Rood et al., 1989; Zhang et al., 2003; Vayenas et al., 2005). We assume that gases and aerosol are in equilibrium, that aerosols are homogenous and internally mixed, and that unaccounted-for factors do not influence the thermodynamics of the system (Vayenas et al., 2005). Calculated $\mathrm{HNO}_{3(\mathrm{~g})}$ mixing ratios were greatest in the afternoon (12:00-16:00 LT), at which time they were $2 \mathrm{ppb}$ on average for the DISCOVER-AQ time period and up to $4-6 \mathrm{ppb}$ on the warmest days only. In the $24 \mathrm{~h}$ average, $\mathrm{HNO}_{3(\mathrm{~g})}$ was $15 \%$ of $\left[\mathrm{NO}_{3}^{-}+\mathrm{HNO}_{3}\right]$ by mass and was $40 \%$ (median) in the afternoon. High $\mathrm{HNO}_{3(\mathrm{~g})}$ was generally simultaneous with the magenta-highlighted $\mathrm{NO}_{3}^{-}$data (Fig. 7). To compute the $v_{\mathrm{d}}$ of $\mathrm{HNO}_{3}$, the equation $\frac{\partial \mathrm{NO}_{3}^{-}}{\partial t}=\frac{v_{\mathrm{d}}}{h} \mathrm{C}$ was solved, with $\frac{\partial \mathrm{NO}_{3}^{-}}{\partial t}$ equal to the observed afternoon loss rate on designated (magenta) days, $C$ equal to the daily mean $\mathrm{HNO}_{3(\mathrm{~g})}$ over the same time windows, and $h$ equal to the maximum boundary layer height (i.e., the afternoon height) visually identified according to aerosol backscatter estimates by a micropulse lidar (MPL) supplemented with a wide-field receiver system (Appendix A). In this way, we derived $v_{\mathrm{d}}$ equal to $5 \pm 2 \mathrm{~cm} \mathrm{~s}^{-1}$, in line with previous direct measurements of $1-10 \mathrm{~cm} \mathrm{~s}^{-1}$ (e.g., Huebert and Robert, 1985; Meyers et al., 1989; Sievering et al., 2001; Volpe Horii et al., 2005; Farmer et al., 2006) and constrained estimates of $6 \mathrm{~cm} \mathrm{~s}^{-1}$ (Vayenas et al., 2005). Given a $v_{\mathrm{d}}$ of $5 \mathrm{~cm} \mathrm{~s}^{-1}$ (assumed constant), the hourly $\frac{\partial \mathrm{NO}_{3}^{-}}{\partial t}$ was computed for every hour of the day, with $C$ equal to the time-varying $\mathrm{HNO}_{3(\mathrm{~g})}$ and $h$ equal to the timevarying boundary layer height. We assume losses are from the entire boundary layer, see Appendix $\mathrm{C}$ for our reasoning. For the daily time-varying $h$ : the NBL was estimated as $10 \%$ of the maximum daytime boundary layer height measured by MPL; the morning increase was estimated as linear over $5 \mathrm{~h}$ and fully developed at 11:00; and the evening (18:00) collapse (also linear) was estimated as occurring in $2 \mathrm{~h}$.

In this way and with respect to surface deposition alone, $\tau_{\mathrm{NO}_{3}^{-}}$was calculated to be $3 \mathrm{~h}$ ( 0.1 days) under daytime conditions. As a lower bound, if the true $v_{\mathrm{d}}$ was at the slowest end of previous observations $\left(1 \mathrm{~cm} \mathrm{~s}^{-1}\right)$, then $\tau_{\mathrm{NO}_{3}^{-}}$would be $14 \mathrm{~h}$ under daytime conditions. Lifetimes in this range are shorter than typical stagnation periods, observed to be $5 \pm 1.5$ days $(1 \sigma)$ in both Fresno and Bakersfield (decadal average). By comparison, $\mathrm{PM}_{1}-\mathrm{PM}_{2.5} v_{\mathrm{d}}$ yield $\tau_{\mathrm{NO}_{3}^{-}}$of 6-58 days. Such long lifetimes indicate the frequency of frontal passages controls the PM lifetime. Because the loss of $\mathrm{NH}_{4} \mathrm{NO}_{3}$ via $\mathrm{HNO}_{3}$ deposition is rapid and $\mathrm{PNO}_{3}^{-}$is relatively large, high aerosol days are expected to be more responsive to changes in emissions than expected when considering loss only through particle deposition.

There are other observational constraints that an account of aerosol $\mathrm{NO}_{3}^{-}$in the SJV should explain. Median $\mathrm{NO}_{3}^{-}$(2001-2013) is $25 \%$ higher in Bakersfield than Fresno (Fig. 2). However, the observationally constrained calculated total $\mathrm{PNO}_{3}^{-}$(NRL plus $\mathrm{OH}$-initiated) is $15 \%$ lower in Bakersfield than Fresno (Fig. 6). We find that wintertime stagnation events, defined as continuous days with increasing $24 \mathrm{~h} \mathrm{PM}_{2.5}$, are more severe in Bakersfield than in Fresno, meaning there is a greater increase in $\mathrm{PM}_{2.5}$ day $^{-1}$ over each event. The median increase in $\mathrm{PM}_{2.5}$ day $^{-1}$ event ${ }^{-1}$ over the last decade was $15 \%$ greater in Bakersfield $\left(7.9 \mathrm{\mu g} \mathrm{m}^{-3} \mathrm{day}^{-1}\right.$ event $\left.^{-1}\right)$ than Fresno $\left(6.7 \mu \mathrm{g} \mathrm{m}^{-3} \mathrm{day}^{-1}\right.$ event $\left.^{-1}\right)$ leading to $23 \%$ larger increases in $\mathrm{PM}_{2.5}$ event ${ }^{-1}$ in Bakersfield $\left(32.5 \mu \mathrm{g} \mathrm{m}^{-3}\right.$ event $\left.^{-1}\right)$ than Fresno $\left(25.1 \mu \mathrm{g} \mathrm{m}^{-3}\right.$ event $\left.^{-1}\right) . \mathrm{PM}_{2.5}$ on the first day of the event was also $20 \%$ higher in Bakersfield $\left(8.6 \mu \mathrm{g} \mathrm{m}^{-3}\right.$ event $^{-1}$ versus $6.9 \mu \mathrm{g} \mathrm{m}^{-3}$ event $\left.^{-1}\right)$. These differences between Bakersfield and Fresno may in part be attributed to the former's location in the southern end of the SJV, where the city is enclosed on three sides by the moun- 
tains, resulting in reduced losses to advection and mixing than in Fresno. Likewise, transport may carry a portion of aerosol produced elsewhere in the valley to Bakersfield, either by advection in the surface-mixed layer or by a nocturnal low-level jet. Weaker correlations $\left(r^{2}\right)$ in Fig. 2 in Bakersfield (0.6) than in Fresno (0.9) serve as evidence for enhanced influences of mixing and transport processes over $\mathrm{NO}_{3}^{-}$concentrations in the southern SJV.

\subsection{Impacts of future $\mathrm{NO}_{x}$ reductions}

California has committed to additional, sizable controls on $\mathrm{NO}_{x}$ emissions, with decreases of at least $50 \%$, and potentially up to $75 \% \mathrm{NO}_{x}$, imminent over the next decade. California has implemented a retrofit/replacement program to accelerate impacts of federal rules on diesel engines, affecting weekday $\mathrm{NO}_{x}$ (Dallmann and Harley, 2010; California Air Resources Board, 2012), and has both tightened standards on gasoline-powered vehicles and required one in seven new cars sold in the state be zero-emission or plug-in hybrids for model years 2017-2025 (Environmental Protection Agency, 2012), affecting weekday and weekend $\mathrm{NO}_{x}$.

Currently, average wintertime $\mathrm{NO}_{x}$ concentrations are low enough that reductions of 50 and $75 \%$ are calculated to decrease $\mathrm{PNO}_{3}^{-}$in the NRL in Bakersfield on weekends by 40 and $70 \%$, respectively (Fig. 8a), with similar results in Fresno and Visalia. Recall, the $\mathrm{NO}_{3}$ radical production is nonlinear versus $\mathrm{NO}_{2}$ and, for a fixed $\mathrm{O}_{x}$ concentration, production is described by a single curve in Fig. B1a. When $\mathrm{O}_{x}$ is variable, $\mathrm{NO}_{3}$ radical production is described by multiple curves and is most sensitive to changes in $\mathrm{O}_{3}$ at $\mathrm{NO}_{2}$ concentrations which are at and/or greater than peak $\mathrm{NO}_{3}$ radical production. At low $\mathrm{NO}_{x}$ (and high $\mathrm{NO}_{x}$ ), $P \mathrm{NO}_{3}^{-}$that is limited by $\mathrm{NO}_{3}$ radical production is more sensitive to changes in $\mathrm{NO}_{2}$. Figure 6 suggests that as a direct result of decreases in $\mathrm{NO}_{2}$, the chemical sensitivity of $P \mathrm{NO}_{3}^{-}$to $\mathrm{NO}_{2}$ has been altered such that future $\mathrm{NO}_{x}$ controls are poised to more effectively slow $\mathrm{PNO}_{3}^{-}$in the NRL in the next decade than over the last, at least at weekend $\mathrm{NO}_{x}$ levels.

We compute that $\mathrm{NO}_{x}$ reductions of 50 and $75 \%$ are large enough that changes in the average wintertime $\mathrm{NO}_{3}^{-}$are quantified via 2.56: 1 line (3.31 including molar equivalent $\mathrm{NH}_{4}^{+}$), the stoichiometric $\mathrm{NO}_{3}^{-}$response to $\mathrm{NO}_{2}$, meaning the $\mathrm{O}_{3}$ feedback from reduced $\mathrm{NO}_{x}$ on $\mathrm{PNO}_{3}^{-}$is minimal. The highest $\mathrm{NO}_{x}$ conditions in the SJV are present in the shallowest boundary layers of December and January; during DISCOVER-AQ, $\mathrm{NO}_{x}$ concentrations were high enough that reduced weekend $\mathrm{NO}_{x}$ (21-22 January) had the effect of increasing $\mathrm{PNO}_{3}^{-}$in the NRL relative to the preceding weekdays, i.e., chemistry on these days was right of peak $\mathrm{NO}_{3}$ radical production.

Our calculation implies greater decreases in $\mathrm{PNO}_{3}^{-}$have occurred in lower- $\mathrm{NO}_{x}$ rural environments than in cities since 2001 given the same relative $\mathrm{NO}_{x}$ reductions. During a previous aerosol experiment, CRPAQS (California Regional
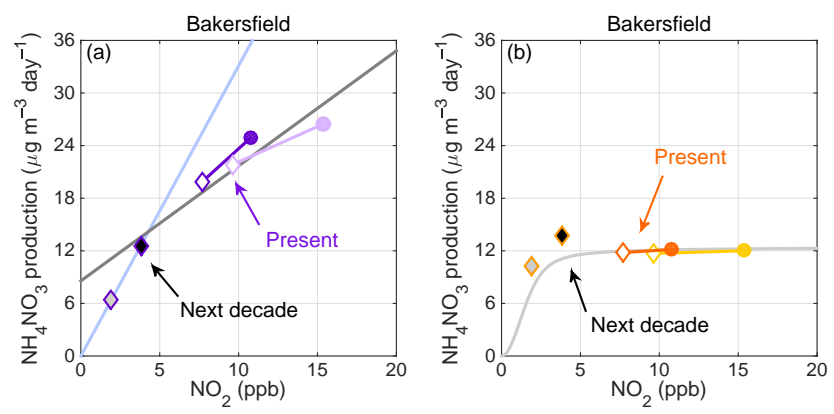

Figure 8. In Bakersfield: tethered 3-year weekday (closed circles) and weekend (open diamonds) medians of calculated wintertime $\mathrm{NH}_{4} \mathrm{NO}_{3}$ production $\left(\mu \mathrm{g} \mathrm{m}^{-3}\right.$ day $\left.^{-1}\right)$ in the NRL (a) and during the daytime (b) versus $\mathrm{NO}_{2}$. Medians and means give the same result. Brighter data are observationally constrained 3-year medians at present (2010-2013). Pale points are observationally constrained 3 -year medians at the start of the record (2001-2004). Predicted $\mathrm{NH}_{4} \mathrm{NO}_{3}$ production at $-50 \%$ weekend $\mathrm{NO}_{x}$ are black-filled diamonds and $-75 \%$ weekend $\mathrm{NO}_{x}$ are gray-filled diamonds. Weekend data were selected simply to expand the $\mathrm{NO}_{x}$ range of individual curves; impacts on weekdays can be inferred. In panel (a), the light blue line is stoichiometric and the gray line is a fit to the annual observations as in Fig. 5. In panel (b), the gray line is the calculated $\mathrm{HNO}_{3}$ production with $P \mathrm{HO}_{x}$ and organic reactivity equal to present-day values.

$\mathrm{PM}_{10} / \mathrm{PM}_{2.5}$ Air Quality Study), conducted December 1999February 2001 (Watson et al., 2000) with a wintertime intensive (15 December 2000-3 February 2001), it was generally observed that high $\mathrm{NH}_{4} \mathrm{NO}_{3}$ was a valley-wide phenomenon. CRPAQS measurements of $24 \mathrm{~h} \mathrm{NO}-$ (November 2000January 2001) were similar in rural locations and in Fresno and Bakersfield, while high organic aerosol concentrations were spatially correlated with the cities. From these data, it was hypothesized that nocturnal low-level currents efficiently transported $\mathrm{NH}_{4} \mathrm{NO}_{3}$ and $\mathrm{NO}_{3}^{-}$precursors, distributing $\mathrm{NH}_{4} \mathrm{NO}_{3}$ and $\mathrm{NH}_{4} \mathrm{NO}_{3}$ production throughout the SJV (Chow et al., 2006). On the contrary, during DISCOVER$\mathrm{AQ}, \mathrm{NO}_{3}^{-}$was observed to spatially correlate with cities. Long-term co-located $\mathrm{NO}_{3}^{-}$and $\mathrm{NO}_{2}$ measurements do not exist at any rural location in the SJV; however, the discrepancy between spatial patterns during DISCOVER-AQ and during CRPAQS can be explained through a combination of $\mathrm{NO}_{x}$ emission controls shrinking urban $\mathrm{NO}_{x}$ plumes and low- $\mathrm{NO}_{x}$ nighttime chemistry being more sensitive to changes in $\mathrm{NO}_{2}$.

For $\mathrm{NO}_{x}$ emission changes to affect daytime $\mathrm{PNO}_{3}^{-}$, they must be large enough to transition photochemistry into the $\mathrm{NO}_{x}$-limited regime, less than a few ppb in the wintertime SJV (Fig. B1b). In Bakersfield (Fig. 8b), at $-50 \% \mathrm{NO}_{x}$ from current levels we predict an increase in daytime $\mathrm{NH}_{4} \mathrm{NO}_{3}$ production of $2 \mu \mathrm{g} \mathrm{m}^{-3} \mathrm{day}^{-1}(\sim 15 \%)$, but at $-75 \% \mathrm{NO}_{x}$, we predict a transition to low- $\mathrm{NO}_{x}$ chemistry and a net decrease in $\mathrm{NH}_{4} \mathrm{NO}_{3}$ production of $1.5 \mu \mathrm{g} \mathrm{m}^{-3}$ day $^{-1}(15 \%)$. 
Initial enhancements in $\mathrm{NH}_{4} \mathrm{NO}_{3}$ are caused by $\mathrm{NO}_{x}$ feedbacks on the $\mathrm{HO}_{x}$ precursors, $\mathrm{O}_{3}$ and $\mathrm{CH}_{2} \mathrm{O}$, which are both predicted to increase in response to decreases in $\mathrm{NO}_{2}$ (Fig. B2). In Fig. 7b, the gray line is the modeled $\mathrm{NH}_{4} \mathrm{NO}_{3}$ production day ${ }^{-1}$ calculated for present day conditions. The modeled points show the results of the calculations, for which the influence of $\mathrm{NO}_{x}$ decreases on $\mathrm{PHO}_{x}$, and the subsequent feedbacks on $\mathrm{NH}_{4} \mathrm{NO}_{3}$ production, are accounted. Elevation of $\mathrm{NH}_{4} \mathrm{NO}_{3}$ production above the gray line is due to the $\mathrm{NO}_{2}-\mathrm{PHO}_{x}$ precursor feedback. In Fresno (not shown), we compute an increase of $0.5 \mathrm{\mu g} \mathrm{m}^{-3} \mathrm{day}^{-1}(<5 \%)$ at $-50 \% \mathrm{NO}_{x}$ and a decrease in $\mathrm{NH}_{4} \mathrm{NO}_{3}$ production of $\sim 3 \mu \mathrm{g} \mathrm{m}^{-3} \mathrm{day}^{-1}(20 \%)$ at $-75 \% \mathrm{NO}_{x}$.

Combining our derived trends in NRL and daytime $\mathrm{PNO}_{3}^{-}$ (Table 1), we calculate impacts of past and future $\mathrm{NO}_{x}$ controls on the frequency of wintertime $24 \mathrm{~h} \mathrm{PM}_{2.5}$ NAAQS exceedances. Using data from a multi-year experiment in the early 2000s in Fresno (Appendix A), the $24 \mathrm{~h} \mathrm{NO}_{3}^{-}$concentration was observed to be an almost constant fraction of $24 \mathrm{~h} \mathrm{PM}_{2.5}$ each winter when $24 \mathrm{~h} \mathrm{PM}_{2.5}$ was greater than $15 \mathrm{\mu g} \mathrm{m}^{-3}$ and an even larger fraction at lower loadings, typically in March. During DISCOVER-AQ, surface aerosol in Fresno was $41 \%$ (median) and $39 \%$ (mean) $\mathrm{NO}_{3}^{-}$in $\mathrm{PM}_{2.5}$, and $57 \%$ (median) and $53 \%$ (mean) $\mathrm{NH}_{4} \mathrm{NO}_{3}$ in $\mathrm{PM}_{2.5}$. Previous work has shown that $\mathrm{NH}_{4} \mathrm{NO}_{3}$ is a smaller portion of total $\mathrm{PM}_{2.5}$ in Fresno than in any other location in the SJV, including Bakersfield, with rural $\mathrm{PM}_{2.5}$ dominated by $\mathrm{NH}_{4} \mathrm{NO}_{3}$ (Zhang et al., 2010). We applied our calculated changes in $\mathrm{PNO}_{3}^{-}$to $50 \%$ of wintertime $\mathrm{PM}_{2.5}$ mass as a conservative estimate. We also assume that $\mathrm{NH}_{4} \mathrm{NO}_{3}$ has been and will continue to be $50 \%$ of the aerosol mass over the entire past and future record. This simplification implies there have and will be only small changes in the heterogeneous loss rate of $\mathrm{N}_{2} \mathrm{O}_{5}$, in the relative speciated $\mathrm{NO}_{3}$ reactivity, and in the fractional product yields of $\mathrm{N}_{2} \mathrm{O}_{5}$ hydrolysis. Figure 2 suggests these factors have not substantially affected the $\mathrm{NO}_{2}$ dependence of $\mathrm{NO}_{3}^{-}$over time, at least in the wintertime average in this location. We find that over the last decade, the impact of $\mathrm{NO}_{x}$ controls on $\mathrm{PNO}_{3}^{-}$, and hence $\mathrm{NH}_{4} \mathrm{NO}_{3}$, has been to reduce the number of $24 \mathrm{~h} \mathrm{PM}_{2.5}$ exceedances by $18-46 \%$ (Table 1 ). The primary mechanism for these changes has been decreased $\mathrm{PNO}_{3}^{-}$in the NRL. Trends in $\mathrm{PO}_{3}^{-}$account for $32-90 \%$ of the total observed change. We hypothesize that controls on the organic portion of aerosol mass, for example district-level amendments to national home wood burning and fireplace rules (San Joaquin Valley Air Pollution Control Board, 2003), may have driven the other portion of reductions.

In the future, a $50 \%$ decrease in $\mathrm{NO}_{x}$ is predicted to decrease $\mathrm{PNO}_{3}^{-}$in the NRL more efficiently and to the point where this source is approximately equal to $\mathrm{OH}$ initiated $\mathrm{PNO}_{3}^{-}$on weekends. If reductions of $75 \% \mathrm{NO}_{x}$ are achieved, $\mathrm{PNO}_{3}^{-}$in the NRL will decrease sufficiently that daytime $\mathrm{OH}$-initiated $\mathrm{HNO}_{3}$ formation is anticipated to become the dominant source of wintertime $\mathrm{NH}_{4} \mathrm{NO}_{3}$ on all days of the week. We calculate that over the next decade the SJV will experience 7-16\% fewer exceedance days with a $50 \%$ decrease in $\mathrm{NO}_{x}$ and $\sim 30 \%$ fewer exceedances with a $75 \%$ decrease in $\mathrm{NO}_{x}$.

We have not considered the impact of $\mathrm{NH}_{3}$ controls because our data indicate $\mathrm{PNO}_{3}^{-}$chemistry, not the $\mathrm{NH}_{3}$ abundance, drives $\mathrm{NH}_{4} \mathrm{NO}_{3}$ (Figs. 2 and 3), and because it has been shown that $\mathrm{NH}_{3}$ emissions in the $\mathrm{SJV}$ are too high for any reasonable $\mathrm{NH}_{3}$ control to affect wintertime $\mathrm{NH}_{4} \mathrm{NO}_{3}$ concentrations (Herner et al., 2006). While these $\mathrm{NO}_{x}$ controls constitute a major improvement to the air quality in the $\mathrm{SJV}$, it is evident that decreases in organic aerosol mass are also required to eliminate high aerosol days in the SJV. We have not quantified, but do expect, future $\mathrm{NO}_{x}$ reductions to influence the production of secondary organic aerosol (SOA) mass. In the laboratory, it has consistently been observed that $\mathrm{NO}_{x}$ concentrations, relative to gas-phase organic compounds, influence the molecular identity and volatility of oxidation products such that SOA yields are higher at low $\mathrm{NO}_{x}$ and suppressed at high $\mathrm{NO}_{x}$ (e.g., Presto et al., 2005; Ng et al., 2007; Kroll and Seinfeld, 2008; Chan et al., 2010). Recent summertime field measurements of aerosolphase $\mathrm{RONO}_{2}$ in Bakersfield (Rollins et al., 2012) and at a forested field site in Colorado (Fry et al., 2013) found that $\mathrm{NO}_{3}$ radical-initiated $\mathrm{SOA}$ formation correlated with $\mathrm{NO}_{3}$ production and was proportional to $\mathrm{NO}_{x}$ at low to moderate $\mathrm{NO}_{x}$ levels. In Fresno during DISCOVER-AQ, SOA constituted $40 \%$ of the organic fraction of $\mathrm{PM}_{1}$, or $22 \%$ of total $\mathrm{PM}_{1}$ mass (Young et al., 2015). Reductions in $\mathrm{NO}_{x}$ as large as 50 to $75 \%$ are expected to influence this portion of the aerosol mass and likely in a way that affects the frequency of exceedances in the SJV; however, the magnitude and sign of the impact are beyond the scope of this work.

Additional benefits of $\mathrm{NO}_{x}$ decreases include reductions in high summertime $\mathrm{O}_{3}$ throughout the SJV (Pusede and Cohen, 2012; Pusede et al., 2014) and decreases in both summertime inorganic nitrate aerosol (Markovic et al., 2014) and $\mathrm{NO}_{3}$-radical initiated SOA (Rollins et al., 2012). Because the US EPA has recently decided to strengthen the annual $\mathrm{PM}_{2.5}$ standard of $12 \mu \mathrm{g} \mathrm{m}^{-3}$ (Environmental Protection Agency, 2013), compliance with this NAAQS in the SJV will require reductions in aerosol concentrations in all seasons. Generally speaking, regulatory policies of valley-wide interpollutant trading of $\mathrm{NO}_{x}$ for $\mathrm{PM}_{2.5}$ control aimed at wintertime $\mathrm{NH}_{4} \mathrm{NO}_{3}$ must be designed with knowledge of each nonlinear $\mathrm{PNO}_{3}^{-}$mechanism versus $\mathrm{NO}_{2}$, instead of use of a single exchange rate, as urban (high- $\mathrm{NO}_{x}$ ) and rural (low$\left.\mathrm{NO}_{x}\right) \mathrm{PNO}_{3}^{-}$are differently responsive to changes in $\mathrm{NO}_{2}$. Finally, because $\mathrm{NO}_{3}^{-}$is concentrated over Fresno and Bakersfield, $\mathrm{NO}_{x}$ reductions need to happen in those cities themselves, prioritizing localized interventions to maximize the public health benefit and probability of regulatory compliance. 
Table 1. Effects of three $\mathrm{NO}_{x}$ emission control scenarios on wintertime $24 \mathrm{~h} \mathrm{PM} 2.5$ NAAQS exceedances in Fresno, Visalia, and Bakersfield. Percentages are calculated according to days in which data exist, not total wintertime days. Rows $1-2$ : average exceedances winter ${ }^{-1}$ (November-March) in the last 3 years of the record, rounded up, and percentage of days in violation. Rows 3-9: number of exceedances predicted after a $50 \%$ increase (back in time) and 50 and $75 \%$ reductions in $\mathrm{NO}_{x}$, including the calculated percent change from present day. In row 3, the number in parentheses is the actual number of exceedances averaged for 2001-2004. In row 5, the number of calculated exceedances was rounded down to compute the percent.

\begin{tabular}{lrrr}
\hline Control & Fresno & Visalia & Bakersfield \\
\hline Exceedances $\left(\right.$ winter $\left.^{-1}\right)$ & 34 & 21 & 34 \\
Winter days in exceedance $(\%)$ & 31 & 14 & 23 \\
\hline$+50 \% \mathrm{NO}_{x}$ & & & \\
\hline Exceedances after the control $\left(\right.$ winter $\left.^{-1}\right)$ & $48(60)$ & $31(31)$ & $40(53)$ \\
$\%$ change in exceedances & 40 & 46 & 18 \\
$\%$ change explained by the $\mathrm{NO}_{x}$ reduction & 50 & 90 & 32 \\
\hline$-50 \% \mathrm{NO}_{x}$ & & & \\
\hline Exceedances after the control $\left(\right.$ winter $\left.^{-1}\right)$ & 32 & 19 & 29 \\
$\%$ change in exceedances & -7 & -10 & -16 \\
\hline -75\% $\mathrm{NO}_{x}$ & & & \\
\hline Exceedances after the control $\left(\right.$ winter $\left.^{-1}\right)$ & 24 & 16 & 24 \\
$\%$ change in exceedances & -31 & -27 & -32 \\
\hline
\end{tabular}

\section{Conclusions}

We derived trends in the wintertime production of $\mathrm{NO}_{3}^{-}$ $\left(\mathrm{PNO}_{3}^{-}\right)$as calculated from measurements of gas-phase precursors over the last 13 years. We used these $\mathrm{PNO}_{3}^{-}$trends to explain the observed $\mathrm{NO}_{3}^{-}$sensitivity to $\mathrm{NO}_{2}$, which was -0.5 and $-0.64 \mu \mathrm{g} \mathrm{m}^{-3} \mathrm{ppb}^{-1} \mathrm{NO}_{2}$ in the San Joaquin Valley cities of Fresno in Bakersfield, respectively. We found that reductions in $\mathrm{NO}_{x}$ have both decreased and increased $\mathrm{NH}_{4} \mathrm{NO}_{3}$ formation rates by the various chemical pathways, but the net downward trend in $\mathrm{NO}_{3}^{-}$has been driven by local changes in nighttime chemistry in residual layers decoupled from fresh surface emissions. We showed that high $\mathrm{NH}_{4} \mathrm{NO}_{3}$ abundances were a combined function of active chemical $\mathrm{PNO}_{3}^{-}$and rapid atmospheric loss by deposition of gas-phase $\mathrm{HNO}_{3}\left(\tau_{\mathrm{NO}_{3}^{-}} \sim 3\right.$ daytime $\left.\mathrm{h}\right)$; in contrast, the total aerosol mass lifetime was controlled by cold fronts that turnover valley air on average every $5 \pm 1.5$ days. We computed the impact of future $\mathrm{NO}_{x}$ decreases on $\mathrm{PNO}_{3}^{-}$ from both nighttime and daytime mechanisms, finding the sign and magnitude of the changes are dependent on oxidation pathway, oxidant precursor, $\mathrm{NO}_{2}$ concentration, and, at night, altitude. We calculated that the SJV will experience $7-16 \%$ fewer days in exceedance of the $24 \mathrm{~h} \mathrm{PM}_{2.5}$ standard with a $50 \% \mathrm{NO}_{x}$ reduction and $\sim 30 \%$ fewer $24 \mathrm{~h}$ $\mathrm{PM}_{2.5}$ exceedance days with a $75 \% \mathrm{NO}_{x}$ reduction. As an additional consequence of anticipated $\mathrm{NO}_{x}$ controls, daytime rather than nighttime chemistry will drive $\mathrm{NH}_{4} \mathrm{NO}_{3}$ production in the SJV in the future. The observations and calculations presented here offer improved insight into the chem- istry imbedded in the wintertime $\mathrm{NH}_{4} \mathrm{NO}_{3}$ diurnal cycles and suggest such long-term measurements would inform the absolute and relative contributions by vertically stratified $\mathrm{NO}_{3}$ chemistry and $\mathrm{OH}$-initiated production, especially if a record that captured diurnal variability were put in place prior to the sizable $\mathrm{NO}_{x}$ reductions that are forthcoming. The specific $\mathrm{NO}_{x}$ constraints on $\mathrm{NH}_{4} \mathrm{NO}_{3}$ chemistry we described here likely inform the effects of $\mathrm{NO}_{x}$ emission changes, both increases and decreases, on aerosol in other polluted cities. 


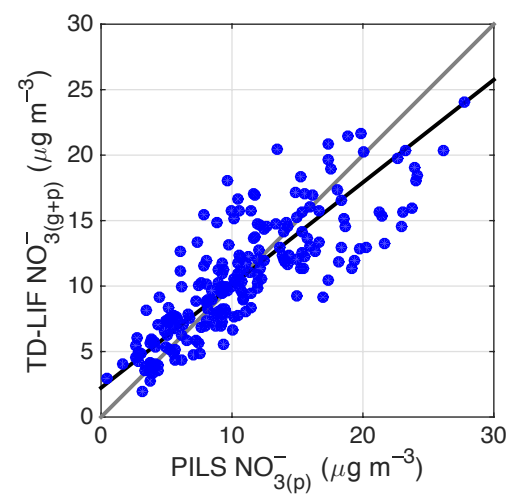

Figure A1. P-3B TD-LIF $\mathrm{NO}_{3}^{-}(\mathrm{g}+\mathrm{p})$ in $\mathrm{PM}_{2.5}$ versus PILS $\mathrm{NO}_{3}^{-}$ in $\mathrm{PM}_{3}$ below $0.5 \mathrm{~km}$ a.s.l. The gray line is one-to-one and the black line is a least squares fit assuming equal weights in $x$ and $y$ data.

\section{Appendix A: Measurements}

\section{A1 Long-term records}

The long-term aerosol $\mathrm{NO}_{3}^{-}$data are from $24 \mathrm{~h}$ integrated filter-based measurements of $\mathrm{PM}_{10}$ collected once every 3 to 6 days as part of the US EPA's Chemical Speciation Network program. The data were downloaded from the California Air Resources Board (CARB) archive (http://www.arb.ca.gov/ aqmis2/aqdselect.php). We used measurements at FresnoFirst Street $\left(36.782^{\circ} \mathrm{N}, 119.773^{\circ} \mathrm{W}\right)$ and Bakersfield-5558 California Avenue $\left(35.357^{\circ} \mathrm{N}, 119.063^{\circ} \mathrm{W}\right)$, as the two stations had mostly uninterrupted records and co-located observations of $\mathrm{NO}_{2}$ and $\mathrm{O}_{3}$. In Fig. 2, Bakersfield $\mathrm{NO}_{3}^{-}$wintertime (November-March) medians include the years 20012013 with an average of 46 weekday and 18 weekend data points year ${ }^{-1}$. The Fresno-First Street station was closed in 2012 and so the Fresno $\mathrm{NO}_{3}^{-}$wintertime medians include 2001-2012 with an average of 36 weekday and 17 weekend data points year ${ }^{-1}$.

To make these $\mathrm{NO}_{3}^{-}$measurements, ambient air is sampled through a denuder and aerosol are collected on a quartz fiber filter for $24 \mathrm{~h}$, midnight to midnight. Water-soluble ions are then quantified by ion chromatography. $\mathrm{NH}_{4} \mathrm{NO}_{3}$ is semivolatile and exists in thermal equilibrium with gas-phase $\mathrm{HNO}_{3}$ and $\mathrm{NH}_{3}$. Long sample collection times $(24 \mathrm{~h})$ and the presence of a denuder result in low biases due to loss of $\mathrm{NO}_{3}^{-}$to the gas phase (Appel et al., 1981; Shaw Jr. et al., 1982; Hering and Cass 1999; Babich et al., 2000). This interference is well documented and observed to be large during summer months, when more than $80 \%$ of $\mathrm{NH}_{4} \mathrm{NO}_{3}$ may be lost, but is estimated to be $\sim 20 \%$ when relative humidities are high and temperatures are cold (Appel et al., 1981; Shaw Jr. et al., 1982; Hering and Cass, 1999). If we assume ambient conditions, as opposed to conditions internal to the instrument, drive the equilibrium (Appel et al., 1981; Shaw Jr. et al., 1982; Hering and Cass, 1999;
Babich et al., 2000), we are able to estimate the interference using surface AMS observations of $\mathrm{NO}_{3}^{-}, \mathrm{NH}_{4}^{+}, \mathrm{Cl}^{-}$, and sulfate $\left(\mathrm{SO}_{4}^{2-}\right)$ and a particle into liquid sampler (PILS) of potassium $\left(\mathrm{K}^{+}\right)$and magnesium $\left(\mathrm{Mg}^{+}\right)$in Fresno during DISCOVER-AQ to constrain the thermodynamic model ISORROPIA II (Nenes et al., 1998; Fountoukis and Nenes, 2007). To do this, we set the total gas plus particle concentration equal to the ion data, running ISORROPIA II in the forward mode to simulate the gas-aerosol partitioning after the air stream passed through a denuder, consistent with all gases being captured by the denuder and all aerosol depositing on the filter. During DISCOVER-AQ, the daily average temperature and relative humidity $(\mathrm{RH})$ were $8.5^{\circ} \mathrm{C}$ and $70 \%$, respectively. Median daytime (08:00-18:00) wintertime temperatures were within $\sim 1{ }^{\circ} \mathrm{C}$ and $1 \% \mathrm{RH}$ in Bakersfield and Fresno. When these conditions drive the interference, we predict that daily-integrated $\mathrm{NO}_{3}^{-}$was biased low by $25 \%$, in line with other reports (Chow et al., 2005). The average wintertime (November-March) temperature and RH at the USDA Shafter Station from 2000 to 2013 were $10^{\circ} \mathrm{C}$ and $79 \%$, respectively. Under these ambient conditions, we predict measurements of the daily-integrated $\mathrm{NO}_{3}^{-}$are biased low by $23 \%$. Evaporative loss of $\mathrm{NO}_{3}^{-}$of $25 \%$ implies the true slope is $20 \%$ greater with respect to the measured value. The observed correlation between $\mathrm{NO}_{3}^{-}$and $\mathrm{NO}_{2}$ indicates $\sim 20 \%$ of $\mathrm{NO}_{2}$ is oxidized to $\mathrm{NO}_{3}^{-}$(Fig. 2), a $20 \% \mathrm{NO}_{3}^{-}$ error implies that $25 \%$ of $\mathrm{NO}_{2}$ is oxidized to $\mathrm{NO}_{3}^{-}$.

Hourly $\mathrm{O}_{3}, 24 \mathrm{~h}$ total $\mathrm{PM}_{2.5}$, and $\mathrm{NO}_{2}$ data are from the CARB archive at the following sites: Fresno-First Street (2000-2011), Fresno-Garland $\left(36.785^{\circ} \mathrm{N}, 119.773^{\circ} \mathrm{W}\right)$ (2011-2013), Visalia-North Church Street $\left(36.333^{\circ} \mathrm{N}\right.$, $\left.119.291^{\circ} \mathrm{W}\right)(2000-2013)$, and Bakersfield-5558 California Avenue (2000-2013). $\mathrm{NO}_{2}$ measurements are made by chemiluminescence coupled to a heated molybdenum catalyst and have a known but poorly quantified positive interference from higher oxides of nitrogen (Winer et al., 1974; Williams et al., 1998; Dunlea et al., 2007). This interference is largest in the summertime when weakly bound higher oxides are more abundant relative to $\mathrm{NO}_{x}$ and minimal in the wintertime. These instruments sample ambient air through a filter, removing $\mathrm{NO}_{3}^{-}$and likely a considerable fraction of gas-phase $\mathrm{HNO}_{3}$ and multifunctional organic nitrates, reducing the positive artifact. $\mathrm{NO}_{2}$ concentrations are decreasing across the valley at a rate similar to that observed from space by OMI, an instrument selective for $\mathrm{NO}_{2}$, suggesting that relative trends in $\mathrm{NO}_{2}$ are accurate (Russell et al., 2010).

Hourly solar radiation, temperature, and $\mathrm{RH}$ data were taken from the California Irrigation Management Information System archive (http://www.cimis.water.ca.gov) at the Shafter US Department of Agriculture (USDA) station $\left(35.530^{\circ} \mathrm{N}, 119.280^{\circ} \mathrm{W}\right)$. Sunrise and sunset times in Bakersfield $\left(35.357^{\circ} \mathrm{N}, 119.063^{\circ} \mathrm{W}\right)$ were downloaded from the 
Table A1. Species, measurement accuracy, analytical technique, time resolution, location/platform, and reference for select DISCOVER-AQ observation included in our analysis. Many compounds are measured with higher precision than accuracy. See original references for details.

\begin{tabular}{llllll}
\hline Species & Accuracy $( \pm \%)$ & Analytical technique & Resolution & Location & Reference(s) \\
\hline $\mathrm{NO}_{3}^{-}$(g+p) & 20 & TD-LIF & $1 \mathrm{~s}$ & P-3B & Day et al. (2002) \\
$\mathrm{PM}_{1}$ ions & 20 & AMS & $20 \mathrm{~min}$ & Fresno-Garland & Drewnick et al. (2005); Ge et al. (2012) \\
$\mathrm{PM}_{2.5}$ ions & 20 & PILS & $20 \mathrm{~min}$ & Fresno-Garland & \\
$\mathrm{NO}_{2}$ & 5 & LIF & $1 \mathrm{~s}$ & P-3B & Thornton et al. (1999) \\
$\mathrm{NH}_{3}$ & 35 & cavity ring down & $8-20 \mathrm{~s}$ & P-3B & Picarro G2103 analyzer \\
$\mathrm{CH}_{2} \mathrm{O}$ & 4 & IR absorption & $1 \mathrm{~s}$ & P-3B & Weibring et al. (2006, 2007) \\
\hline
\end{tabular}

United States Naval Observatory Naval Oceanography Portal (http://aa.usno.navy.mil/data/docs/RS_OneYear.php).

Nitrate ion observations with $10 \mathrm{~min}$ time resolution were available during select time periods and were used to determine the wintertime variability in the fraction of $\mathrm{PM}_{2.5}$ that was $\mathrm{NO}_{3}^{-}$. There data were collected in Fresno in 20002001 and 2003-2005 (Watson et al., 2000) as part of the EPA PM Supersites program (http://www.epa.gov/ttnamti1/ supersites.html). These measurements were made by flash volatilizing $\mathrm{NH}_{4} \mathrm{NO}_{3}$, reducing $\mathrm{HNO}_{3}$ across a heated catalyst to nitric oxide (NO), and detecting $\mathrm{NO}$ by chemiluminescence (Stolzenburg et al., 2003; Chow et al., 2008). It was reported that $24 \mathrm{~h}$ averages of these high-time-resolution observations were well correlated with, but 20-40\% lower than, $24 \mathrm{~h} \mathrm{PM} 2.5$ filter samples (annual averages). This effect has been attributed to incomplete volatilization and/or incomplete catalytic conversion of $\mathrm{NO}_{3}^{-}$to NO. Two identical instruments at the Fresno supersite yielded data that were also well correlated but different by $10-55 \%$ in the annual average (Chow et al., 2008). As a result, we treat these observations as uncalibrated but internally consistent over time.

\section{A2 DISCOVER-AQ observations}

The DISCOVER-AQ experiment synchronized multiple ground sites and aircraft sampling of in situ and column measurements, producing a data set resolved in space, both horizontally and vertically, and in time. The DISCOVERAQ sampling strategy was built on repeated sampling across urban-rural (horizontal) and vertical gradients and on connecting observations made from balloons, onboard aircraft, and from space to monitoring sites at the surface. The NASA P-3B aircraft flew only during daylight hours, completing $2-3$ identical circuits day ${ }^{-1}$, alternating low-altitude ( $150 \mathrm{~m}$ a.g.1.), along the valley's western edge, medium-low (300 $\mathrm{m}$ a.g.l.), and high-altitude flight passes (2.6 km a.g.l.). Circuits included missed approaches at all cities and rural waypoints when visibility permitted. Missed approaches allowed the P-3B to reach altitudes as low as $20-40 \mathrm{~m}$ (a.g.l.) and were conducted over airstrips. Landing strips were often rural and little trafficked but may have experienced airportrelated $\mathrm{NO}_{x}$ enhancements in the cities of Fresno and Bakersfield.
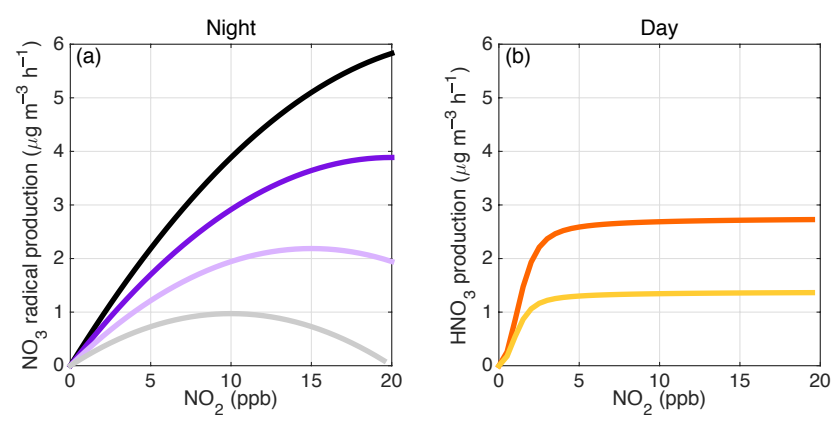

Figure A2. Panel (a): nighttime $\mathrm{NO}_{3}$ radical production $\left(\mu \mathrm{g} \mathrm{m}^{-3} \mathrm{~h}^{-1}\right)$ versus $\mathrm{NO}_{2}$ (ppb) under four $\mathrm{O}_{x}$ conditions: $50 \mathrm{ppbO}_{x}$ (black), $40 \mathrm{ppbO}_{x}$ (purple), $30 \mathrm{ppbO}_{x}$ (violet), and $20 \mathrm{ppb} \mathrm{O}_{x}$ (gray). The temperature is $282 \mathrm{~K}$ and $\mathrm{NO}_{3}$ radical production is scaled by two, i.e., all $\mathrm{NO}_{3}$ reacts with $\mathrm{NO}_{2}$ and $\mathrm{N}_{2} \mathrm{O}_{5}$ hydrolysis is rapid compared to $\mathrm{NO}_{3}$ formation. Panel (b): daytime production of $\mathrm{HNO}_{3}\left(\mu \mathrm{g} \mathrm{m}^{-3} \mathrm{~h}^{-1}\right)$ as a function of $\mathrm{NO}_{2}$ computed with an analytical model at $\mathrm{NO}: \mathrm{NO}_{x}=0.3$ and $\mathrm{VOCR}=4 \mathrm{~s}^{-1}$ at $0.3 \mathrm{ppt} \mathrm{s}^{-1} \mathrm{PHO}_{x}$ (orange) and $0.15 \mathrm{ppt} \mathrm{s}^{-1} \mathrm{PHO}_{x}$ (golden).

The comprehensive suite of DISCOVER-AQ data is available to the public at https://www-air.larc.nasa.gov/cgi-bin/ ArcView/discover-aq.ca-2013. Table A1 lists the measurement accuracy, analytical technique, platform and location, and associated references of species key to this analysis.

The $\mathrm{NO}_{3}^{-}(\mathrm{g}+\mathrm{p})$ measurements were made by thermal dissociation laser induced fluorescence (TD-LIF). The TD-LIF operating principle is as follows: $\mathrm{NO}_{2}$ is detected by laserinduced fluorescence (LIF) (Thornton et al., 1999). A tunable dye laser is pumped by a Q-switched, frequency doubled $\mathrm{Nd}^{3+}$ :YAG laser. The narrow band dye laser is etalontuned to a specific $585 \mathrm{~nm}$ rovibronic feature of $\mathrm{NO}_{2}$, alternating between this feature and the weaker continuum absorption. The resulting red-shifted photons are imaged onto a photomultiplier tube and collected using time-gated counting. The LIF technique is spectroscopically specific and accurate $( \pm 5 \%)$. The system was calibrated in flight every $\sim 30$ min with an $\mathrm{NO}_{2}$ reference standard added at the inlet. The higher oxides of nitrogen, peroxy nitrates $\left(\mathrm{RO}_{2} \mathrm{NO}_{2}\right)$, alkyl nitrates $\left(\mathrm{RONO}_{2}\right)$, and $\mathrm{HNO}_{3}$ were measured by thermal dissociation (TD) coupled to LIF (Day et al., 2002). 
Dissociation of thermally labile species into $\mathrm{NO}_{2}$ and a companion radical occurs at characteristic temperatures due to differing $\mathrm{N}-\mathrm{O}$ bond strengths. Ambient air is pulled through heated quartz tube ovens followed by PFA sampling lines before reaching the $\mathrm{NO}_{2}$ detection cell. An unheated channel detects only $\mathrm{NO}_{2}$, a second channel $\left(180^{\circ} \mathrm{C}\right)$ measures $\mathrm{NO}_{2}+\mathrm{RO}_{2} \mathrm{NO}_{2}$, a third channel $\left(400^{\circ} \mathrm{C}\right)$ measures $\mathrm{NO}_{2}+\mathrm{RO}_{2} \mathrm{NO}_{2}+\mathrm{RONO}_{2(\mathrm{~g}+\mathrm{p})}$, and a fourth $\left(600^{\circ} \mathrm{C}\right)$ measures $\mathrm{NO}_{2}+\mathrm{RO}_{2} \mathrm{NO}_{2}+\mathrm{RONO}_{2(\mathrm{~g}+\mathrm{p})}+\mathrm{NO}_{3}^{-}(\mathrm{g}+\mathrm{p})$. Mixing ratios of each species are determined as the difference between adjacent channels, i.e., $\mathrm{NO}_{3}^{-}(\mathrm{g}+\mathrm{p})$ equals the $600^{\circ} \mathrm{C}$ channel minus the signal in the $400^{\circ} \mathrm{C}$ channel. $\mathrm{ClNO}_{2}$ is thought to appear primarily in the $400{ }^{\circ} \mathrm{C}$ channel. Recent observations indicated that about $50 \%$ of $\mathrm{ClNO}_{2}$ was observed in the $400{ }^{\circ} \mathrm{C}$ channel and $50 \%$ in the $600{ }^{\circ} \mathrm{C}$ channel. Residence times in the ovens are sufficient to volatilize aerosol-bound nitrates, which is reflected in the $\mathrm{RONO}_{2(\mathrm{~g}+\mathrm{p})}+\mathrm{NO}_{3}^{-}(\mathrm{g}+\mathrm{p})$ subscripting (Day et al., 2002).

$\left.\mathrm{NO}_{3}-\bar{p}\right)$ was measured onboard the P-3B by a PILS system sampling at $4 \mathrm{~min}$ time resolution with a well-characterized $\sim 3 \mu \mathrm{m}$ aerosol size cutoff. In Fig. A1, 4 min averaged $\mathrm{NO}_{3(\mathrm{~g}+\mathrm{p})}^{-}$measured by TD-LIF is compared against PILS $\mathrm{NO}_{3}^{-}$(p) when the aircraft was below $0.5 \mathrm{~km}$ a.s.l. The data are fit using a linear least squares model that assumes equally weighted errors in both measurements. Reported uncertainties in the TD-LIF and PILS observations are 15 and $20 \%$, respectively, and they correlate $(y=0.8 x+2.3)$ within combined uncertainties of $25 \%$. The TD-LIF is sensitive to $\mathrm{HNO}_{3(\mathrm{~g})}$, while the PILS is not. Using ISORROPIA II (described in Sect. 4.2) $\mathrm{HNO}_{3(\mathrm{~g})}$ is predicted to be up to a few $\mathrm{ppb}$ in the afternoon, corresponding to the highest temperatures but not to the highest $\mathrm{NO}_{3}^{-}$(p) (Fig. 7). Additional details on the TD-LIF aircraft inlet configuration are found in Perring et al. (2009) and Wooldridge et al. (2010).

\section{A3 Data and filtering for boundary layer sampling}

Occasionally the height of the daytime boundary layer was observed near the altitude of the P-3B's low-level flight legs, requiring analysis to distinguish between free troposphere and boundary layer air. Within boundary layer sampling was identified using $1 \mathrm{~s}^{-1}$ measurements of $\mathrm{NO}$ and $\mathrm{RH}$ recorded by the aircraft data system, according to steep discontinuities in both tracers, being high in the boundary layer and low aloft. In some cases, $\mathrm{H}_{2} \mathrm{O}_{(v)}$ measured by diode laser hygrometer and $\mathrm{O}_{3}$ were also considered. In Fig. 3 in addition to filtering for within boundary layer sampling, data were only plotted when the pressure altitude (a.s.l.) was greater than 0 .

For our derivation of $\tau_{\mathrm{NO}_{3}^{-}}$, boundary layer depth was estimated with data from an MPL located in the town of Porterville during DISCOVER-AQ. The MPL was supplemented with a wide-field receiver system that allowed for improved near-range signal recovery of the $527 \mathrm{~nm}$ attenuated backscatter profiles that were recorded at $30 \mathrm{~m}$ vertical and 1 min time resolutions. For daytime mixed-layer conditions driven by convection, the aerosol gradient falls off and stable molecular scatter signal above the lowest mixed aerosol layer signal represents the boundary layer height. According to this aerosol gradient, boundary layer heights were observed to range from 300 to $700 \mathrm{~m}$ during DISCOVER-AQ. 

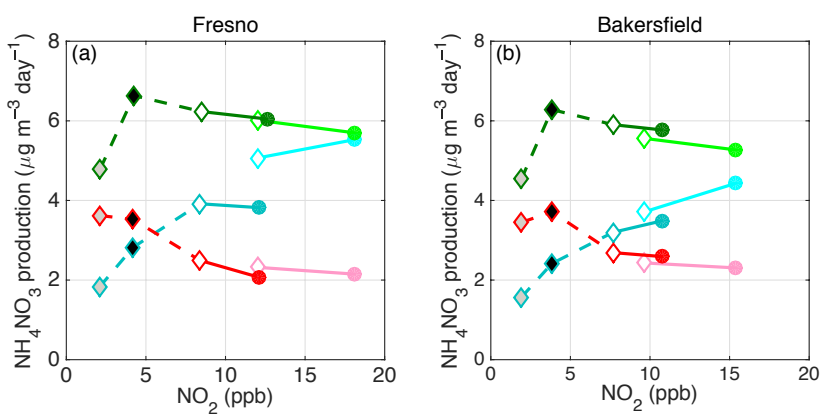

Figure B1. Wintertime $\mathrm{NH}_{4} \mathrm{NO}_{3}^{-}$production $\left(\mu \mathrm{g} \mathrm{m}^{-3}\right.$ day $\left.{ }^{-1}\right)$ by OH-initiated chemistry versus daytime (10:00-15:00 LT) $\mathrm{NO}_{2}$ (ppb) for each individual $\mathrm{HO}_{x}$ precursor: $\mathrm{O}\left({ }^{1} \mathrm{D}\right)+\mathrm{H}_{2} \mathrm{O}$ (red), $\mathrm{HONO}$ (turquoise), and $\mathrm{CH}_{2} \mathrm{O}$ (green). Data are tethered presentday 3-year medians on weekdays (closed circles) and weekends (open diamonds) in Fresno (a) and Bakersfield (b). Lighter tint data are tethered 3-year medians at the start of the record (2001-2004). There is no significant difference between medians and means. Predicted $\mathrm{NH}_{4} \mathrm{NO}_{3}^{-}$production calculated at $-50 \%$ weekend $\mathrm{NO}_{x}$ $\left(\mathrm{NO}_{x}\right.$ black-filled diamond) and $-75 \%$ weekend $\mathrm{NO}_{x}$ (gray-filled diamond) are also shown.

\section{Appendix B: Calculating $\mathrm{PNO}_{3}^{-}$}

The chemistry producing $\mathrm{NO}_{3}$ radical at night and $\mathrm{HNO}_{3}$ in the daytime is shown in Fig. $\mathrm{B} 1$ as a function of $\mathrm{NO}_{2}$. The production of $\mathrm{NO}_{3}$ radical $\left(\mu \mathrm{g} \mathrm{m}^{-3} \mathrm{~h}^{-1}\right)$ is calculated at four initial $\mathrm{O}_{x}\left(\mathrm{O}_{x} \equiv \mathrm{NO}_{2}+\mathrm{O}_{3}\right)$ conditions: $50 \mathrm{ppb} \mathrm{O}_{x}$ (black), $40 \mathrm{ppb} \mathrm{O}_{x}$ (purple), $30 \mathrm{ppb} \mathrm{O}_{x}$ (violet), and $20 \mathrm{ppb}$ $\mathrm{O}_{x}$ (gray). In Fig. $\mathrm{B} 1 \mathrm{~b}$, the production of $\mathrm{HNO}_{3}$ is shown for two $\mathrm{PHO}_{x}$ conditions: $0.3 \mathrm{ppts}^{-1} \mathrm{PHO}_{x}$ (orange) and $0.15 \mathrm{ppt} \mathrm{s}^{-1} \mathrm{PHO}_{x}$ (golden). For the sake of the night-day comparison, in Fig. $\mathrm{B} 1 \mathrm{NO}_{3}$ radical production is scaled by two, which assumes all $\mathrm{NO}_{3}$ reacts with $\mathrm{NO}_{2}$ and that $\mathrm{N}_{2} \mathrm{O}_{5}$ hydrolysis is rapid compared to $\mathrm{NO}_{2}+\mathrm{O}_{3}$. In this analysis, we compute $\mathrm{PNO}_{3}^{-}$as $\mathrm{NO}_{3}$ radical production scaled by the observationally constrained $\mathrm{NO}_{3}$ radical reactivity yielding $\mathrm{NO}_{3}^{-}$(see text below).

\section{B1 $\mathrm{NO}_{3}$-initiated $\mathrm{PNO}_{3}^{-}$in the nocturnal residual layer}

Our time-dependent box model of $\mathrm{NO}_{3}$ radical production was run separately for each day over the time period 20002013. The model was initialized with hourly $\mathrm{O}_{3}$ measurements at the surface using the maximum $\mathrm{O}_{3}$ concentration 1$3 \mathrm{~h}$ before sunset and the median daytime (10:00-15:00 LT) $\mathrm{NO}_{x}$. This window was determined based on the timing of steep afternoon $\mathrm{O}_{3}$ titration observed in the hourly surface $\mathrm{O}_{3}$ data, both during DISCOVER-AQ and throughout the interannual record. $\mathrm{O}_{3}$ and $\mathrm{NO}_{x}$ were treated as well mixed in the daytime boundary layer and $k_{\mathrm{NO}_{2}+\mathrm{O}_{3}}$ was calculated based on the mean surface temperature at 18:00-20:00 LT. $\mathrm{NO}_{3}$ radical production was integrated from sunset to $1 \mathrm{~h}$ prior to sunrise. Differences were insignificant using mean $\mathrm{O}_{3}$ over this time window versus the daily maximum.

Although there is no long-term, vertically resolved measurement record of any species in the region, there is observational evidence that the rapid decline in afternoon $\mathrm{O}_{3}$ corresponds to the stratification of the daytime boundary layer. First, as part of CRPAQS, measurements of $\mathrm{NO}, \mathrm{O}_{3}$, and $\mathrm{NO}_{3}^{-}$were made simultaneously atop a tower $(90 \mathrm{~m}$ a.g.l.) and at a lower level (7 ma.g.1.) in the SJV town of Angiola. Winter average (December 2000-January 2001) NO and $\mathrm{O}_{3}$ at the two sampling heights were comparable from 10:00 to 13:00 LT; however, by 14:00 LT the concentrations began to diverge, with $\mathrm{O}_{3}$ at $7 \mathrm{~m}$ falling rapidly $\left(\sim 5 \mathrm{ppbh}^{-1}\right)$, concurrent with increases in $\mathrm{NO}$, while $\mathrm{O}_{3}$ at $90 \mathrm{~m}$ remaining approximately constant until sunset, whereupon a decrease of $\sim 2 \mathrm{ppbh}^{-1}$ was observed. NO at the $90 \mathrm{~m}$ level was near 0 throughout the night. A 7-day time series of $\mathrm{NO}_{3}^{-}$data at $90 \mathrm{~m}$ showed clear increases in $\mathrm{NO}_{3}^{-}$beginning at nightfall and persisting until sunrise of $\sim 10 \mu \mathrm{g} \mathrm{m}^{-3}$ (Brown et al., 2006). These diurnal patterns suggest that the NRL(s) decouple from the surface layer $\sim 3 \mathrm{~h}$ prior to sunset and that initial concentrations of the nocturnal chemistry reactants, $\mathrm{NO}_{2}$ and $\mathrm{O}_{3}$, are also represented by surface concentrations $3 \mathrm{~h}$ prior to sunset. During DISCOVER-AQ, full vertical profiling by the P-3B (including a missed approach) concluded in Fresno at 14:30-15:30, $\sim 2-3 \mathrm{~h}$ prior to sunset. Profiles of $\mathrm{O}_{3}$ and the conserved tracer $\mathrm{O}_{x}$ suggest that stratification of the daytime boundary layer had begun by this time on multiple afternoons, although day-to-day variability was observed. A comparison of mean $\mathrm{O}_{3}$ and $\mathrm{O}_{x}$ concentrations in the top $100 \mathrm{~m}(\sim 0.35-0.45 \mathrm{~km}$ a.s.1.) and bottom $100 \mathrm{~m}$ $(\sim 0.15-0.05 \mathrm{~km}$ a.s.l.) of the atmosphere below the height of the daytime boundary layer, found small differences in $\mathrm{O}_{x}$ on all flight days but, on some days, large differences in $\mathrm{O}_{3} \cdot \mathrm{O}_{3}$ variations equaled $25-30 \%$ the mean $\mathrm{O}_{3}$ profile concentration on two days, 18 and 22 January 2013. At midday (12:0013:00) at the same altitudes, small absolute differences were observed in both $\mathrm{O}_{3}$ and $\mathrm{O}_{x}$.

Reaction fates of the $\mathrm{NO}_{3}$ radicals calculated by the timedependent box model described above were determined according to the mean proportional $\mathrm{NO}_{3}$ reactivity contributions observed during DISCOVER-AQ. $\mathrm{NO}_{3}$ Reactions (BR3-BR5) are as follows:

$\mathrm{NO}_{3}+\mathrm{NO}_{2}+M \rightarrow \mathrm{N}_{2} \mathrm{O}_{5}+M$,

$(\mathrm{BR} 1)$

$\mathrm{NO}_{3}+$ alkene $\rightarrow \mathrm{RONO}_{2}$,

$\mathrm{NO}_{3}+$ aldehyde or alcohol or dimethyl sulfide

$$
\rightarrow \mathrm{HNO}_{3}+\text { products. }
$$

Each of the three pathways results in a different number of $\mathrm{NO}_{3}^{-}$produced per $\mathrm{NO}_{3}$ radical. $\mathrm{NO}_{3}$ reactivities are defined as $k_{\mathrm{N}_{2} \mathrm{O}_{5}} \mathrm{~K}_{\mathrm{eq}}(T)\left[\mathrm{NO}_{2}\right]$ (Brown 
et al., 2003, 2009), $\sum_{i} k_{\mathrm{NO}_{3}+\text { alkene }_{i}}\left[\right.$ alkene $\left._{i}\right], \quad$ and $\sum_{i}\left(k_{\mathrm{NO}_{3}+\text { alcohol }_{i}}\left[\right.\right.$ alcohol $\left._{i}\right]+k_{\mathrm{NO}_{3}+\text { aldehyde }_{i}}\left[\right.$ aldehyde $\left._{i}\right]$ $\left.+k_{\mathrm{NO}_{3}+\mathrm{DMS}}[\mathrm{DMS}]\right)$, for Reactions (BR3), (BR4), and

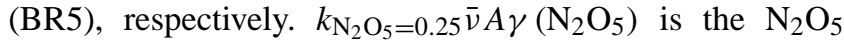
uptake coefficient and $\mathrm{K}_{\mathrm{eq}}(T)$ is Reaction (R3) equilibrium constant. For $k_{\mathrm{N}_{2} \mathrm{O}_{5}}, \bar{v}$ is the $\mathrm{N}_{2} \mathrm{O}_{5}$ mean molecular speed, $A$ is the aerosol surface area density, and $\gamma\left(\mathrm{N}_{2} \mathrm{O}_{5}\right)$ is the $\mathrm{N}_{2} \mathrm{O}_{5}$ aerosol uptake coefficient. $A$ was determined as the product of the dry surface area of particles $60-1000 \mathrm{~nm}$ in diameter measured by an ultra-high sensitivity aerosol spectrometer and the hygroscopic growth factor, $f(\mathrm{RH})$, calculated from the signal difference of a two nephelometers, one sampling dried air $(\mathrm{RH}<40 \%)$ and a second sampling after humidification to $80 \% \mathrm{RH}$ (each measurement was made onboard the P-3B). During DISCOVER-AQ, below $0.4 \mathrm{~km}$ a.s.l., the mean dry surface area was $191.8 \pm 75 \mu \mathrm{m}^{2} \mathrm{~cm}^{-3}(1 \sigma)$ and the mean $f(\mathrm{RH})$ was $1.7 \pm 0.2(1 \sigma) \cdot \gamma\left(\mathrm{N}_{2} \mathrm{O}_{5}\right)$ was set equal to 0.006 as estimated from the parameterization in Bertram and Thornton (2009) following Wagner et al. (2013): $30 \mathrm{M}$ aerosol water and an aerosol system including only water, $\mathrm{NH}_{4}^{+}$, and $\mathrm{NO}_{3}^{-}$. Using the aerosol water, $\mathrm{NH}_{4}^{+}$, and $\mathrm{NO}_{3}^{-}$ that we computed by ISORROPIA II, $\mathrm{NO}_{3}^{-}$constituted $45 \%$ aerosol mass. We assume that all $\mathrm{N}_{2} \mathrm{O}_{5}$ was converted to $2 \mathrm{NO}_{3}^{-}$. If $\mathrm{ClNO}_{2}$ formation is an important $\mathrm{N}_{2} \mathrm{O}_{5}$ hydrolysis product in the SJV, we have overestimated the total $\mathrm{NO}_{3}^{-}$ production. While there is limited observational insight into the extent of $\mathrm{ClNO}_{2}$ formation, because $\mathrm{ClNO}_{2}$ is predicted to thermally dissociate in the $\mathrm{RONO}_{2}$ channel of the TD-LIF instrument (reviewed in Perring et al., 2013), in the early morning, a portion of the measured quantity $\mathrm{RONO}_{2(\mathrm{~g}+\mathrm{p})}$ is possibly due to $\mathrm{ClNO}_{2}$. On all days, the P-3B flights began at $\sim 08: 00 \mathrm{LT}$, which is early enough to capture at least portion of nocturnal $\mathrm{ClNO}_{2}$ prior to photolysis. The mean $\mathrm{RONO}_{2(\mathrm{~g}+\mathrm{p})}$ before 10:00 and below $0.4 \mathrm{~m}$ a.s.l is equivalent to $1.6 \mu \mathrm{g} \mathrm{m}^{-3} \mathrm{NO}_{3}^{-}$, or $15 \%$ of measured $\mathrm{NO}_{3}^{-}(\mathrm{g}+\mathrm{p})$. However, there is little discernable loss of $\mathrm{RONO}_{2(\mathrm{~g}+\mathrm{p})}$ in the late morning, which would be expected if the $\mathrm{RONO}_{2}(\mathrm{~g}+\mathrm{p})$ was due to $\mathrm{ClNO}_{2}$, suggesting $15 \%$ is an upper limit.

$\mathrm{NO}_{3}$ reactivities were computed using the DISCOVERAQ data set with daytime (13:00-17:00 LT) surface observations of $\mathrm{NO}_{2}$, organic compounds (whole air canister sampling), and dimethyl sulfide (DMS) (whole air canister sampling). $\mathrm{CH}_{2} \mathrm{O}$ measurements from onboard the $\mathrm{P} 3$-B were included in the speciated reactivity for Reaction (BR5). Little temporal variability was observed in the concentrations of organic compounds between 13:00 and 17:00 LT. If alkenes reactive with $\mathrm{NO}_{3}$ in NRL are oxidized by $\mathrm{OH}$ or $\mathrm{O}_{3}$ prior to nightfall, then $\sum_{i} k_{\mathrm{NO}_{3}+\text { alkene }_{i}}$ [alkene $i$ ] represents an overestimate. This will alter the absolute value of the calculated change in $\mathrm{PNO}_{3}^{-}$but not the functional form of the dependence. To account for this, we decrease the concentrations of organic species by one e-fold prior to computing the $\mathrm{NO}_{3}$ reactivity.

In Fresno and Bakersfield the reaction of $\mathrm{NO}_{2}$ with $\mathrm{NO}_{3}$ represented $\sim 80 \%$ of total $\mathrm{NO}_{3}$ reactivity, with negligible weekday-weekend differences. The mean $\mathrm{NO}_{3}$ reactivity values used in the model were $0.005 \mathrm{~s}^{-1}$ for addition to double bonds, yielding $0 \mathrm{HNO}_{3} ;<0.001 \mathrm{~s}^{-1}$ for hydrogen abstraction, yielding $1 \mathrm{HNO}_{3}$; and $0.02 \mathrm{~s}^{-1}$ for reaction with $\mathrm{NO}_{2}$, which after heterogeneous conversion of $\mathrm{N}_{2} \mathrm{O}_{5}$ yields $2 \mathrm{HNO}_{3}$. This gives $1.5 \mathrm{NO}_{3}^{-}$produced per $\mathrm{NO}_{3}$ on average. The integrated $\mathrm{PNO}_{3}^{-}$was taken as the $\mathrm{NO}_{3}$ radical production scaled by the $\mathrm{NO}_{3}$ reactivity to $\mathrm{NO}_{2}$, which assumed reactions with alkenes and DMS were instantaneous. This result is similar to that of the wintertime NACHTT experiment at comparable relative $\mathrm{NO}_{2}$ concentrations (Wagner et al., 2013). During $\mathrm{NACHTT} \mathrm{NO}_{3}$ and $\mathrm{N}_{2} \mathrm{O}_{5}$ were measured, the kinetics of $\mathrm{N}_{2} \mathrm{O}_{5}$ explicitly included in the calculation of $P \mathrm{NO}_{3}^{-}$, and $1.6 \mathrm{HNO}_{3}$ per $\mathrm{NO}_{3}$ radical produced was inferred.

\section{B2 $\mathrm{NO}_{3}$-initiated $\mathrm{PNO}_{3}^{-}$in the nocturnal boundary layer}

The production of $\mathrm{NO}_{3}$ radical was directly computed from surface measurements of hourly $\mathrm{O}_{3}, \mathrm{NO}_{2}, \mathrm{NO}$, and temperature each day from 2000 to $2013 . \mathrm{NO}_{3}$ production was integrated between sunset and $1 \mathrm{~h}$ prior to sunrise and scaled by $1.1 \mathrm{NO}_{3}^{-}$produced per $\mathrm{NO}_{3}$, which is the result from the $\mathrm{NO}_{3}$ reactivity calculation described above with no organic reactivity loss. There were times that under conditions of very high $\mathrm{NO}$ that nighttime $\mathrm{O}_{3}$ was observed to be positive and constant at nonphysical values of $1-10 \mathrm{ppb}$ for multiple hours. This offset was interpreted as a measurement artifact as excess $\mathrm{NO}$ titrates $\mathrm{O}_{3}$ completely. To account for this, when $\mathrm{NO}_{x}$ was greater than 5 times the reported $\mathrm{O}_{3}, \mathrm{O}_{3}$ was set equal to 0 prior to computing $\mathrm{NO}_{3}$ production. However, concentrations of DMS and organic emissions, largely anthropogenic in origin in the wintertime SJV, are predicted to be higher in the NBL than in the daytime boundary layer.

\section{B3 OH-initiated $\mathrm{PNO}_{3}^{-}$}

The integrated daily production of $\mathrm{HNO}_{3}$ was calculated for each day from 2000 to 2013 separately for each of the three $\mathrm{HO}_{x}$ sources: $\mathrm{O}\left({ }^{1} \mathrm{D}\right)+\mathrm{H}_{2} \mathrm{O}$, HONO photolysis, and $\mathrm{CH}_{2} \mathrm{O}$ photolysis (Eq. B1). $P \mathrm{NO}_{3}^{-}$versus $\mathrm{NO}_{2}$ attributed to each $\mathrm{HO}_{x}$ source is plotted in Fig. B2. OH was modeled with an analytical model constrained to DISCOVERAQ observations, built on the assumption that oxidizing radicals were in steady state (Eq. B2) and that $\mathrm{RO}_{2}$ and $\mathrm{HO}_{2}$ production are approximately equal, as are $\mathrm{RO}_{2}$ production and loss, giving Eq. (B3) for both $\mathrm{RO}_{2}$ and $\mathrm{HO}_{2}$ (Murphy et al., 2007). The symbol $\alpha$ is the $\mathrm{RONO}_{2}$ branching ratio. $\mathrm{RO}_{2} \mathrm{NO}_{2}$ are considered to be in thermal equilibrium with $\mathrm{NO}_{2}$ and peroxy radicals and therefore not to contribute to 
net radical formation. Calculated wintertime $\mathrm{OH}$ values were $\sim 10^{6}$ molecules $\mathrm{cm}^{-3}$ at noontime and exhibited reasonable nonlinear $\mathrm{NO}_{2}$ dependence throughout the day. Observational inputs to the model were $\mathrm{NO}$ and $\mathrm{NO}_{2}$, the total organic reactivity to $\mathrm{OH}$ (VOCR), $P \mathrm{HO}_{x}, \alpha$, and temperature. VOCR was computed as equal to $\sum_{i} k_{\mathrm{OH}+\mathrm{VOC}_{i}}\left[\mathrm{VOC}_{i}\right]$ using whole air samples of speciated organic molecules collected at the ground during DISCOVER-AQ and $\mathrm{CH}_{2} \mathrm{O}$ data from onboard the P-3B, as VOCR equal to $\sum_{i} k_{\mathrm{OH}+\mathrm{VOC}_{i}}$ [ $\mathrm{VOC}_{i}$ ]. The daytime average was $\sim 4 \mathrm{~s}^{-1}$, consistent with a recent analysis of the temperature dependence of total VOCR in Bakersfield (Pusede et al., 2014), giving confidence that the majority of the reactivity was accounted for. The $\alpha$ is set equal to $2 \%$. Equations (B2) and (B3) are combined to solve for $\mathrm{OH}$.

$$
\begin{gathered}
P \mathrm{HO}_{x}=2 j_{\mathrm{O}_{3} \rightarrow \mathrm{O}^{1} \mathrm{D}}\left[\mathrm{O}_{3}\right] \frac{k\left[\mathrm{H}_{2} \mathrm{O}\right]}{k\left[\mathrm{H}_{2} \mathrm{O}\right]+k\left[\mathrm{~N}_{2}+\mathrm{O}_{2}\right]} \\
+2 j_{\mathrm{CH}_{2} \mathrm{O}}\left[\mathrm{CH}_{2} \mathrm{O}\right]+j_{\mathrm{HONO}}[\mathrm{HONO}]
\end{gathered}
$$

$$
\begin{aligned}
& P \mathrm{HO}_{x}=L \mathrm{HO}_{x}=2 k_{\mathrm{HO}_{2}+\mathrm{HO}_{2}}\left[\mathrm{HO}_{2}\right]^{2} \\
& \quad+2 k_{\mathrm{HO}_{2}+\mathrm{RO}_{2}}\left[\mathrm{HO}_{2}\right]\left[\mathrm{RO}_{2}\right]+2 k_{\mathrm{RO}_{2}+\mathrm{RO}_{2}}\left[\mathrm{RO}_{2}\right]^{2} \\
& \quad+k_{\mathrm{NO}_{2}+\mathrm{OH}}\left[\mathrm{NO}_{2}\right][\mathrm{OH}]+\alpha k_{\mathrm{NO}+\mathrm{RO}_{2}}[\mathrm{NO}]\left[\mathrm{RO}_{2}\right]
\end{aligned}
$$

$$
\left[\mathrm{RO}_{2}\right] \sim\left[\mathrm{HO}_{2}\right]=\frac{\mathrm{VOCR}[\mathrm{OH}]}{(1-\alpha) k_{\mathrm{NO}+\mathrm{RO}_{2}}[\mathrm{NO}]}
$$

Noontime $j_{\mathrm{O}_{3}}, j_{\mathrm{HONO}}$, and $j_{\mathrm{CH}_{2} \mathrm{O}}$ were computed with the TUV calculator, http://cprm.acd.ucar.edu/Models/TUV/ Interactive_TUV (Madronich, 1987), on a clear-sky day (20 January, 2013), scaled by the ratio of the TUV $j_{\mathrm{NO}_{2}}$ and a measurement of $j_{\mathrm{NO}_{2}}$ made onboard the P-3B, and combined with the diurnally varying long-term record of solar radiation.

The trend in $\mathrm{O}\left({ }^{1} \mathrm{D}\right)+\mathrm{H}_{2} \mathrm{O}$ was calculated from the observational record of $\mathrm{O}_{3}, \mathrm{RH}$, and solar radiation.

No multi-year measurements of HONO have been reported in US cities. HONO is formed at night by a mechanism functionally equivalent to the conversion of two $\mathrm{NO}_{2}$ to one gas-phase HONO and one ground-surface adsorbed $\mathrm{HNO}_{3}$ molecule (Finlayson-Pitts et al., 2003). We computed HONO as equal to $4 \%$ the nighttime (10:00-18:00 LT) mean $\mathrm{NO}_{2}$ (Stutz et al., 2004), yielding one HONO data point for each day. This HONO initialized a calculation wherein photolytic loss was computed, giving HONO concentrations at $1 \mathrm{~h}$ time resolution. We have not accounted for daytime formation; however, in total, daytime source(s) are weekdayweekend independent (Pusede et al., 2015).
The interannual trend in $\mathrm{CH}_{2} \mathrm{O}$ is also unconstrained with observations. In the winter, $\mathrm{CH}_{2} \mathrm{O}$ is not monitored at the surface and cannot be quantified from space due to low column concentrations and shallow daytime boundary layers. $\mathrm{CH}_{2} \mathrm{O}$ is a primary organic emission from agricultural activities associated with animal feeds (Howard et al., 2010), dairy cows (Shaw et al., 2007), and combustion. State inventories offer little insight into $\mathrm{CH}_{2} \mathrm{O}$ trends, as it is unknown whether a priori accounts are complete. $\mathrm{CH}_{2} \mathrm{O}$ is also the oxidation product of most organic molecules in the atmosphere. We calculated the $\mathrm{CH}_{2} \mathrm{O}$ concentration using a 0-D chemical model constrained to the complete $1 \mathrm{~min}$ DISCOVERAQ data set. All 95 organic molecules measured by whole air sampling at the ground level at the Fresno site were included after scaling by a fit to aircraft carbon monoxide. Within the boundary layer, modeled $\mathrm{CH}_{2} \mathrm{O}$ typically captured $75 \%$ of the $\mathrm{CH}_{2} \mathrm{O}$ measured on the $\mathrm{P}-3 \mathrm{~B}$, with the discrepancy most likely due to the local primary $\mathrm{CH}_{2} \mathrm{O}$ emissions. We ran the model under four $\mathrm{NO}_{x}$ reduction scenarios, $-75 \%$ $\mathrm{NO}_{x},-50 \% \mathrm{NO}_{x},+50 \% \mathrm{NO}_{x}$, and $+75 \% \mathrm{NO}_{x}$ assuming the portion of $\mathrm{CH}_{2} \mathrm{O}$ not captured by our model remained constant. At $50 \%$ higher $\mathrm{NO}_{x}$, i.e., at the start of the record, secondary $\mathrm{CH}_{2} \mathrm{O}$ was $\sim 10 \%$ lower on weekdays and $\sim 5 \%$ lower on weekends than in the base model (2013 conditions). At $-50 \%$ and $-75 \% \mathrm{NO}_{x}$, in the next decade, secondary $\mathrm{CH}_{2} \mathrm{O}$ is predicted to increase by $15-25 \%$ from 2013 weekend $\mathrm{NO}_{x}$ levels, as reductions in $\mathrm{NO}_{x}$ increase $\mathrm{OH}$.

The integrated wintertime $24 \mathrm{~h} \mathrm{NH} \mathrm{NHO}_{3}$ production for each of the three $\mathrm{HO}_{x}$ sources is shown in Fig. B2, along with the projected response of to changes in $\mathrm{NO}_{x}$ of $-50 \%$ and $-75 \%$ from weekend concentrations. $\mathrm{PNO}_{3}^{-}$attributed to $\mathrm{O}\left({ }^{1} \mathrm{D}\right)+\mathrm{H}_{2} \mathrm{O}$ is $2-3 \mu \mathrm{g} \mathrm{m}{ }^{-3} \mathrm{day}^{-1}(2000-2013)$ and has increased by $\sim 0.1 \mu \mathrm{g} \mathrm{m}^{-3} \mathrm{ppb}^{-1} \mathrm{NO}_{2}$ in all three SJV cities. It is an order of magnitude smaller than $\mathrm{PNO}_{3}^{-}$in the NRL in the wintertime average. $\mathrm{NH}_{4} \mathrm{NO}_{3}$ production attributed to $\mathrm{HONO}$ has decreased with reduced $\mathrm{NO}_{2}$, i.e., the trend has the correct sign compared to $\mathrm{NO}_{3}^{-}$concentrations (Fig. 2). Declines in HONO have resulted in a decrease in $\mathrm{NH}_{4} \mathrm{NO}_{3}$ production of 3-6 $\mu \mathrm{g} \mathrm{m}^{-3}$ day $^{-1}$ over the entire $\mathrm{NO}_{2}$ range. We find that $\mathrm{CH}_{2} \mathrm{O}$, observed to be $2.3 \pm 1.1 \mathrm{ppb}$ $(1 \sigma)$ in Fresno and $2.0 \pm 0.9 \mathrm{ppb}$ in Bakersfield, has been the largest contributor to photochemical production of $\mathrm{NH}_{4} \mathrm{NO}_{3}$ at $\sim 6 \mu \mathrm{g} \mathrm{m}^{-3}$ day $^{-1} \mathrm{NO}_{3}^{-}$. 


\section{Appendix C: Additional details regarding $\tau_{\mathrm{NO}_{3}}^{-}$}

The timing of decoupling between the NBL and the NRL(s) has implications for our derivation of $\tau_{\mathrm{NO}_{3}^{-}}$. Observed daily $\frac{\partial \mathrm{NO}_{3}^{-}}{\partial t}$ are consistent with the majority of $\mathrm{NO}_{3}^{-}$lost via deposition of $\mathrm{HNO}_{3(\mathrm{~g})}$ from most of the daytime boundary layer. If loss occurred from only the lowest $50 \mathrm{~m}$ of the daytime boundary layer, then the observationally derived $\mathrm{HNO}_{3(\mathrm{~g})} v_{\mathrm{d}}$ would be only $0.4 \mathrm{~cm} \mathrm{~s}^{-1}$, below direct measurements (e.g., Huebert and Robert, 1985; Meyers et al., 1989; Sievering et al., 2001; Volpe Horii et al., 2005; Farmer et al., 2006). Gaseous $\mathrm{HNO}_{3}$ that does not deposit will repartition to the aerosol phase when temperatures fall and $\mathrm{RH}$ rises in the evening. Assuming an NBL height of 50-100 m, then a nighttime rise (black data in Fig. 7) of 10-5 fold is expected. An $\mathrm{NO}_{3}^{-}$concentration of $10 \mu \mathrm{g} \mathrm{m}^{-3}$ shifted to the gas phase would increase by $100-50 \mu \mathrm{g} \mathrm{m}^{-3}$ at nightfall. By contrast, typical nighttime increases were $0-15 \mu \mathrm{g} \mathrm{m}^{-3}$.
In Fig. C1 we show low-altitude (20-350 m a.g.l.) observations from the $\mathrm{P}-3 \mathrm{~B}$ colored by $\mathrm{NO}_{3}^{-}(\mathrm{g}+\mathrm{p})$ concentration over the city of Visalia on 5 flight days as evidence that afternoon decreases are net $\mathrm{HNO}_{3}+\mathrm{NO}_{3}^{-}$loss and not a shift in partitioning between the two species. In each panel the lefthand flight track was at midday (12:00-13:00 LT) and the right-hand track, shifted in space by $0.02^{\circ}$ longitude for visual clarity, was in afternoon (15:00-16:00 LT). On each of the five flights, $\sim 2$-fold higher concentrations of $\mathrm{NO}_{3}^{-}(\mathrm{g}+\mathrm{p})$ were observed at midday compared to a few hours later. Additionally, the reduction in $\mathrm{NO}_{3}^{-}(\mathrm{g}+\mathrm{p})$ is apparent at the higher altitudes, shown in the top and bottom third of each panel, suggesting the loss in $\mathrm{NO}_{3}^{-}$measured by AMS at the surface in Fresno does extend up to at least 300-350 $\mathrm{m}$ a.g.l.

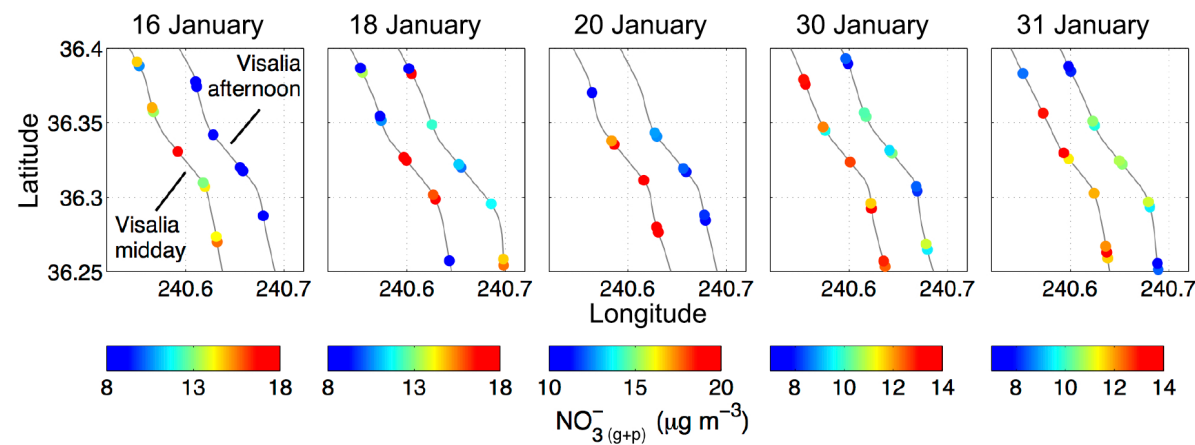

Figure C1. $\mathrm{NO}_{3}^{-}(\mathrm{g}+\mathrm{p})\left(\mu \mathrm{g} \mathrm{m}^{-3}\right)$ in $\mathrm{PM}_{2.5}$ measured during 10 missed approaches on 5 days over Visalia. The left-hand flight track is the midday (12:00-13:00 LT) missed approach and the right-hand track, shifted east by $0.02^{\circ}$, is the afternoon (15:00-16:00 LT) missed approach. 
Acknowledgements. This work was funded by NASA under grant NNX10AR36G. Q. Zhang and C. D. Cappa were also supported by the California Air Resources Board (contract no. 14-307). We acknowledge use of publicly available data maintained by the US EPA, California Air Resources Board, and California Irrigation Management Information System. We thank John Barrick for the $j_{\mathrm{NO}_{2}}$ and $\mathrm{RH}$ (PDS) data, Glenn Diskin for the $\mathrm{H}_{2} \mathrm{O}_{(v)}$ (DLH) data, Luke Ziemba and Lee Thornhill for the $f(\mathrm{RH})$ and UHSAS data, and Donald Blake for the speciated organic compound data. We thank Melinda Beaver for assistance interpreting the long-term ozone data. We thank Steve S. Brown for his feedback during the review process. This analysis would not have been possible without the work of the pilots, crew, and engineers of the NASA P-3B.

Edited by: N. M. Donahue

\section{References}

American Lung Association, State of the air: 2014 report: http: //www.stateoftheair.org/2014/assets/ALA-SOTA-2014-Full.pdf (last access: 27 March 2015), 2014.

Appel, B. R., Tokiwa, Y., and Haik, M.: Sampling of nitrates in ambient air, Atmos. Environ., 15, 283-289, doi:10.1016/00046981(81)90029-9, 1981.

Babich, P., Davey, M., Allen, G., and Koutrakis, P.: Method comparisons for particulate nitrate, elemental carbon, and $\mathrm{PM}_{2.5}$ mass in seven U.S. cities, J. Air Waste Ma., 50, 1095-1105, doi:10.1080/10473289.2000.10464152, 2000.

Bao, J. W., Michelson, S. A., Persson, P. O. G., Djalalova, I. V., and Wilczak, J. M.: Observed and WRF-Simulated LowLevel Winds in a High-Ozone Episode during the Central California Ozone Study, J. Appl. Meteorol. Clim., 47, 2372-2394, doi:10.1175/2008JAMC1822.1, 2008.

Bertram, T. H. and Thornton, J. A.: Toward a general parameterization of $\mathrm{N}_{2} \mathrm{O}_{5}$ reactivity on aqueous particles: the competing effects of particle liquid water, nitrate and chloride, Atmos. Chem. Phys., 9, 8351-8363, doi:10.5194/acp-9-8351-2009, 2009.

Bianco, L., Djalalova, I. V., King, C. W., and Wilczak, J. M.: Diurnal evolution and annual variability of boundary-layer height and its correlation to other meteorological variables in California's Central Valley, Bound.-Lay. Meteorol., 140, 491-511, doi:10.1007/s10546-011-9622-4, 2011.

Brown, S. S. and Stutz, J.: Nighttime radical observations and chemistry, Chem. Soc. Rev., 41, 6405-6447, doi:10.1039/C2CS35181A, 2012.

Brown, S. G., Hyslop, N. P., Roberts, P. T., McCarthy, M. C., and Lurmann, F. W.: Wintertime vertical variations in particulate matter (PM) and precursor concentrations in the San Joaquin Valley during the California Regional Coarse PM/Fine PM Air Quality Study, J. Air Waste Ma., 56, 1267-1277, doi:10.1080/10473289.2006.10464583, 2006.

Brown, S. S., Stark, H., and Ravishankara, A. R.: Applicability of the steady state approximation to the interpretation of atmospheric observations of $\mathrm{NO}_{3}$ and $\mathrm{N}_{2} \mathrm{O}_{5}$, J. Geophys. Res., 108, 4539, doi:10.1029/2003JD003407, 2003.

Brown, S. S., Dubé, W. P., Osthoff, H. D., Wolfe, D. E., Angevine, W. M., and Ravishankara, A. R.: High resolution vertical distributions of $\mathrm{NO}_{3}$ and $\mathrm{N}_{2} \mathrm{O}_{5}$ through the nocturnal boundary layer,
Atmos. Chem. Phys., 7, 139-149, doi:10.5194/acp-7-139-2007, 2007.

Brown, S. S., Dube, W. P., Fuchs, H., Ryerson, T. B., Wollny, A. G., Brock, C. A., Bahreini, R., Middlebrook, A. M., Neuman, J. A., Atlas, E., Roberts, J. M., Osthoff, H. D., Trainer, M., Fehsenfeld, F. C., and Ravishankara, A. R.: Reactive uptake coefficients for $\mathrm{N}_{2} \mathrm{O}_{5}$ determined from aircraft measurements during the Second Texas Air Quality Study: comparison to current model parameterizations, J. Geophys. Res.-Atmos., 114, D00F10, doi:10.1029/2008jd011679, 2009.

California Air Resources Board, Truck and bus regulation-current regulation and advisories, http://www.arb.ca.gov/msprog/ onrdiesel/regulation.htm (last access: 7 January 2016), 2012.

Chan, A. W. H., Chan, M. N., Surratt, J. D., Chhabra, P. S., Loza, C. L., Crounse, J. D., Yee, L. D., Flagan, R. C., Wennberg, P. O., and Seinfeld, J. H.: Role of aldehyde chemistry and $\mathrm{NO}_{x}$ concentrations in secondary organic aerosol formation, Atmos. Chem. Phys., 10, 7169-7188, doi:10.5194/acp-10-7169-2010, 2010.

Chen, L. W. A., Watson, J. G., Chow, J. C., and Magliano, K. L.: Quantifying $\mathrm{PM}_{2.5}$ source contributions for the San Joaquin Valley with multivariate receptor models, Environ. Sci. Technol., 41, 2818-2826, doi:10.1021/es0525105, 2007.

Chow, J., Watson, J., Lowenthal, D., Park, K., Doraiswamy, P., Bowers, K., and Bode, R.: Continuous and filter-based measurements of $\mathrm{PM}_{2.5}$ nitrate and sulfate at the Fresno Supersite, Environ. Monit. Assess., 144, 179-189, doi:10.1007/s10661-0079987-5, 2008.

Chow, J. C., Watson, J. G., Lowenthal, D. H., and Magliano, K. L.: Loss of $\mathrm{PM}_{2.5}$ nitrate from filter samples in Central California, J. Air Waste Ma., 55, 1158-1168, doi:10.1080/10473289.2005.10464704, 2005.

Chow, J. C., Chen, L. W. A., Watson, J. G., Lowenthal, D. H., Magliano, K. A., Turkiewicz, K., and Lehrman, D. E.: $\mathrm{PM}_{2.5}$ chemical composition and spatiotemporal variability during the California Regional $\mathrm{PM}_{10} / \mathrm{PM}_{2.5}$ Air Quality Study (CRPAQS), J. Geophys. Res.-Atmos., 111, D10S04, doi:10.1029/2005jd006457, 2006.

Clarisse, L., Shephard, M. W., Dentener, F., Hurtmans, D., CadyPereira, K., Karagulian, F., Van Damme, M., Clerbaux, C., and Coheur, P.-F.: Satellite monitoring of ammonia: a case study of the San Joaquin Valley, J. Geophys. Res.-Atmos., 115, D13302, doi:10.1029/2009jd013291, 2010.

Cosman, L. M. and Bertram, A. K.: Reactive uptake of $\mathrm{N}_{2} \mathrm{O}_{5}$ on aqueous $\mathrm{H}_{2} \mathrm{SO}_{4}$ solutions coated with 1-component and 2component monolayers, J. Phys. Chem. A, 112, 4625-4635, doi:10.1021/jp8005469, 2008.

Dallmann, T. R. and Harley, R. A.: Evaluation of mobile source emission trends in the United States, J. Geophys. Res.-Atmos., 115, D14305, doi:10.1029/2010jd013862, 2010.

Dallmann, T. R., DeMartini, S. J., Kirchstetter, T. W., Herndon, S. C., Onasch, T. B., Wood, E. C., and Harley, R. A.: On-road measurement of gas and particle phase pollutant emission factors for individual heavy-duty diesel trucks, Environ. Sci. Technol., 46, 8511-8518, doi:10.1021/es301936c, 2012.

Day, D. A., Wooldridge, P. J., Dillon, M. B., Thornton, J. A., and Cohen, R. C.: A thermal dissociation laser-induced fluorescence instrument for in situ detection of $\mathrm{NO}_{2}$, peroxy nitrates, alkyl nitrates, and $\mathrm{HNO}_{3}$, J. Geophys. Res.-Atmos., 107, 4046, doi:10.1029/2001JD000779, 2002. 
Dentener, F. J. and Crutzen, P. J.: Reaction of $\mathrm{N}_{2} \mathrm{O}_{5}$ on tropospheric aerosols - impact on the global distributions of $\mathrm{NO}_{x}, \mathrm{O}_{3}$, and $\mathrm{OH}$, J. Geophys. Res.-Atmos., 98, 7149-7163, doi:10.1029/92jd02979, 1993.

Drewnick, F., Hings, S. S., DeCarlo, P., Jayne, J. T., Gonin, M., Fuhrer, K., Weimer, S., Jimenez, J. L., Demerjian, K. L., Borrmann, S., and Worsnop, D. R.: A new Time-of-Flight Aerosol Mass Spectrometer (TOF-AMS) - instrument description and first field deployment, Aerosol Sci. Technol., 39, 637-658, doi:10.1080/02786820500182040, 2005.

Dunlea, E. J., Herndon, S. C., Nelson, D. D., Volkamer, R. M., San Martini, F., Sheehy, P. M., Zahniser, M. S., Shorter, J. H., Wormhoudt, J. C., Lamb, B. K., Allwine, E. J., Gaffney, J. S., Marley, N. A., Grutter, M., Marquez, C., Blanco, S., Cardenas, B., Retama, A., Ramos Villegas, C. R., Kolb, C. E., Molina, L. T., and Molina, M. J.: Evaluation of nitrogen dioxide chemiluminescence monitors in a polluted urban environment, Atmos. Chem. Phys., 7, 2691-2704, doi:10.5194/acp-7-2691-2007, 2007.

Environmental Protection Agency, California's advanced clean cars program: http://www.arb.ca.gov/msprog/clean_cars/ accsummary-final.pdf (last access: 7 January 2016), 2012.

Environmental Protection Agency, EPA revises the National Ambient Air Quality Standards for particle pollution: https://www. gpo.gov/fdsys/pkg/FR-2013-01-15/pdf/2012-30946.pdf (last access: 7 January 2016), 2013.

Farmer, D. K., Wooldridge, P. J., and Cohen, R. C.: Application of thermal-dissociation laser induced fluorescence (TD-LIF) to measurement of $\mathrm{HNO}_{3}$, $\Sigma$ alkyl nitrates, $\Sigma$ peroxy nitrates, and $\mathrm{NO}_{2}$ fluxes using eddy covariance, Atmos. Chem. Phys., 6, 3471-3486, doi:10.5194/acp-6-3471-2006, 2006.

Farmer, D. K., Chen, Q., Kimmel, J. R., Docherty, K. S., Nemitz, E., Artaxo, P. A., Cappa, C. D., Martin, S. T., and Jimenez, J. L.: Chemically resolved particle fluxes over tropical and temperate forests, Aerosol Sci. Technol., 47, 818-830, doi:10.1080/02786826.2013.791022, 2013.

Finlayson-Pitts, B. J., Wingen, L. M., Sumner, A. L., Syomin, D., and Ramazan, K. A.: The heterogeneous hydrolysis of $\mathrm{NO}_{2}$ in laboratory systems and in outdoor and indoor atmospheres: An integrated mechanism, Phys. Chem. Chem. Phys., 5, 223-242, doi:10.1039/b208564j, 2003.

Flechard, C. R., Spirig, C., Neftel, A., and Ammann, C.: The annual ammonia budget of fertilised cut grassland - Part 2: Seasonal variations and compensation point modeling, Biogeosciences, 7 , 537-556, doi:10.5194/bg-7-537-2010, 2010.

Fountoukis, C. and Nenes, A.: ISORROPIA II: a computationally efficient thermodynamic equilibrium model for $\mathrm{K}^{+}$$\mathrm{Ca}^{2+}-\mathrm{Mg}^{2+}-\mathrm{NH}_{4}^{+}-\mathrm{Na}^{+}-\mathrm{SO}_{4}^{2-}-\mathrm{NO}_{3}^{-}-\mathrm{Cl}^{-}-\mathrm{H}_{2} \mathrm{O}$ aerosols, Atmos. Chem. Phys., 7, 4639-4659, doi:10.5194/acp-7-4639-2007, 2007.

Fry, J. L., Draper, D. C., Zarzana, K. J., Campuzano-Jost, P., Day, D. A., Jimenez, J. L., Brown, S. S., Cohen, R. C., Kaser, L., Hansel, A., Cappellin, L., Karl, T., Hodzic Roux, A., Turnipseed, A., Cantrell, C., Lefer, B. L., and Grossberg, N.: Observations of gas- and aerosol-phase organic nitrates at BEACHON-RoMBAS 2011, Atmos. Chem. Phys., 13, 8585-8605, doi:10.5194/acp-138585-2013, 2013.

Ge, X., Setyan, A., Sun, Y., and Zhang, Q.: Primary and secondary organic aerosols in Fresno, California during wintertime: results from high resolution aerosol mass spectrometry, J. Geophys. Res.-Atmos., 117, D19301, doi:10.1029/2012JD018026, 2012.

Gilliland, A. B., Appel, K. W., Pinder, R. W., and Dennis, R. L.: Seasonal $\mathrm{NH}_{3}$ emissions for the continental united states: inverse model estimation and evaluation, Atmos. Environ., 40, 49864998, doi:10.1016/j.atmosenv.2005.12.066, 2006.

Goebes, M. D., Strader, R., and Davidson, C.: An ammonia emission inventory for fertilizer application in the United States, Atmos. Environ., 37, 2539-2550, doi:10.1016/s13522310(03)00129-8, 2003.

Hallquist, M., Stewart, D. J., Stephenson, S. K., and Cox, R. A.: Hydrolysis of $\mathrm{N}_{2} \mathrm{O}_{5}$ on sub-micron sulfate aerosols, Phys. Chem. Chem. Phys., 5, 3453-3463, doi:10.1039/b301827j, 2003.

Heald, C. L., Collett Jr., J. L., Lee, T., Benedict, K. B., Schwandner, F. M., Li, Y., Clarisse, L., Hurtmans, D. R., Van Damme, M., Clerbaux, C., Coheur, P.-F., Philip, S., Martin, R. V., and Pye, H. O. T.: Atmospheric ammonia and particulate inorganic nitrogen over the United States, Atmos. Chem. Phys., 12, 10295-10312, doi:10.5194/acp-12-10295-2012, 2012.

Hering, S. and Cass, G.: The magnitude of bias in the measurement of $\mathrm{PM}_{2.5}$ arising from volatilization of particulate nitrate from teflon filters, J. Air Waste Ma., 49, 725-733, doi:10.1080/10473289.1999.10463843, 1999.

Herner, J. D., Ying, Q., Aw, J., Gao, O., Chang, D. P. Y., and Kleeman, M. J.: Dominant mechanisms that shape the airborne particle size and composition distribution in Central California, Aerosol Sci. Technol., 40, 827-844, doi:10.1080/02786820600728668, 2006.

Holets, S. and Swanson, R. N.: High-inversion fog episodes in Central California, J. Appl. Meteorol., 20, 890-899, doi:10.1175/1520-0450(1981)020<0890:HIFEIC>2.0.CO;2, 1981.

Howard, C. J., Kumar, A., Malkina, I., Mitloehner, F., Green, P. G., Flocchini, R. G., and Kleeman, M. J.: Reactive organic gas emissions from livestock feed contribute significantly to ozone production in Central California, Environ. Sci. Technol., 44, 23092314, doi:10.1021/es902864u, 2010.

Hu, J. H. and Abbatt, J. P. D.: Reaction probabilities for $\mathrm{N}_{2} \mathrm{O}_{5}$ hydrolysis on sulfuric acid and ammonium sulfate aerosols at room temperature, J. Phys. Chem. A, 105, 871-878, doi:10.1021/jp9627436, 1997.

Huebert, B. J. and Robert, C. H.: The dry deposition of nitric acid to grass, J. Geophys. Res.-Atmos., 90, 2085-2090, doi:10.1029/JD090iD01p02085, 1985.

Jacob, D. J., Waldman, J. M., Munger, J. W., and Hoffmann, M. R.: A field investigation of physical and chemical mechanisms affecting pollutant concentrations in fog droplets, Tellus, 36, 272285, doi:10.1111/j.1600-0889.1984.tb00247.x, 1984.

Jacob, D. J., Munger, J. W., Waldman, J. M., and Hoffmann, M. R.: The $\mathrm{H}_{2} \mathrm{SO}_{4}-\mathrm{HNO}_{3}-\mathrm{NH}_{3}$ system at high humidities and in fogs. 1. Spatial and temporal patterns in the San Joaquin Valley of California, J. Geophys. Res.-Atmos., 91, 1073-1088, doi:10.1029/JD091iD01p01073, 1986a.

Jacob, D. J., Waldman, J. M., Munger, J. W., and Hoffmann, M. R.: The $\mathrm{H}_{2} \mathrm{SO}_{4}-\mathrm{HNO}_{3}-\mathrm{NH}_{3}$ system at high humidities and in fogs. 2. Comparison of field data with thermodynamic calculations, J. Geophys. Res.-Atmos., 91, 1089-1096, doi:10.1029/JD091iD01p01089, 1986 b. 
Kelly, J. T., Baker, K. R., Nowak, J. B., Murphy, J. G., Markovic, M. Z., VandenBoer, T. C., Ellis, R. A., Neuman, J. A., Weber, R. J., Roberts, J. M., Veres, P. R., de Gouw, J. A., Beaver, M. R., Newman, S., and Misenis, C.: Fine-scale simulation of ammonium and nitrate over the South Coast Air Basin and San Joaquin Valley of California during CalNex-2010, J. Geophys. Res.-Atmos., 119, 3600-3614, doi:10.1002/2013jd021290, 2014.

Kroll, J. H. and Seinfeld, J. H.: Chemistry of secondary organic aerosol: formation and evolution of low-volatility organics in the atmosphere, Atmos. Environ., 42, 3593-3624, doi:10.1016/j.atmosenv.2008.01.003, 2008.

Macintyre, H. L. and Evans, M. J.: Sensitivity of a global model to the uptake of $\mathrm{N}_{2} \mathrm{O}_{5}$ by tropospheric aerosol, Atmos. Chem. Phys., 10, 7409-7414, doi:10.5194/acp-10-7409-2010, 2010.

Madronich, S.: Photodissociation in the atmosphere .1. Actinic flux and the effects of ground reflections and clouds, J. Geophys. Res.-Atmos., 92, 9740-9752, doi:10.1029/JD092iD08p09740, 1987.

Markovic, M. Z., VandenBoer, T. C., Baker, K. R., Kelly, J. T., and Murphy, J. G.: Measurements and modeling of the inorganic chemical composition of fine particulate matter and associated precursor gases in California's San Joaquin Valley during CalNex 2010, J. Geophys. Res.-Atmos., 119, 6853-6866, doi:10.1002/2013JD021408, 2014.

McDonald, B. C., Dallmann, T. R., Martin, E. W., and Harley, R. A.: Long-term trends in nitrogen oxide emissions from motor vehicles at national, state, and air basin scales, J. Geophys. Res.Atmos., 117, D00V18, doi:10.1029/2012jd018304, 2012.

McNeill, V. F., Patterson, J., Wolfe, G. M., and Thornton, J. A.: The effect of varying levels of surfactant on the reactive uptake of N2O5 to aqueous aerosol, Atmos. Chem. Phys., 6, 1635-1644, doi:10.5194/acp-6-1635-2006, 2006.

Meyers, T. P., Huebert, B. J., and Hicks, B. B.: $\mathrm{HNO}_{3}$ deposition to a deciduous forest, Bound.-Lay. Meteorol., 49, 395-410, doi:10.1007/BF00123651, 1989.

Munger, J. W., Jacob, D. J., Waldman, J. M., and Hoffmann, M. R.: Fogwater chemistry in an urban atmosphere, J. Geophys. Res.Oc. Atm., 88, 5109-5121, doi:10.1029/JC088iC09p05109, 1983.

Murphy, J. G., Day, D. A., Cleary, P. A., Wooldridge, P. J., Millet, D. B., Goldstein, A. H., and Cohen, R. C.: The weekend effect within and downwind of Sacramento - Part 1: Observations of ozone, nitrogen oxides, and VOC reactivity, Atmos. Chem. Phys., 7, 5327-5339, doi:10.5194/acp-7-5327-2007, 2007.

Nelson, H. H. and Johnston, H. S.: Kinetics of the reaction of $\mathrm{Cl}$ with $\mathrm{ClNO}$ and $\mathrm{ClNO}_{2}$ and the photochemistry of $\mathrm{ClNO}_{2}$, J. Phys. Chem., 85, 3891-3896, doi:10.1021/j150625a036, 1981.

Nenes, A., Pandis, S., and Pilinis, C.: ISORROPIA: a new thermodynamic equilibrium model for multiphase multicomponent inorganic aerosols, Aquat. Geochem., 4, 123-152, doi:10.1023/A:1009604003981, 1998.

Ng, N. L., Kroll, J. H., Chan, A. W. H., Chhabra, P. S., Flagan, R. C., and Seinfeld, J. H.: Secondary organic aerosol formation from $m$-xylene, toluene, and benzene, Atmos. Chem. Phys., 7, 3909-3922, doi:10.5194/acp-7-3909-2007, 2007.

Pandis, S. N. and Seinfeld, J. H.: On the interaction between equilibration processes and wet or dry deposition, Atmos. Environ. Part A - Gen., 24, 2313-2327, doi:10.1016/09601686(90)90325-H, 1990.
Perring, A. E., Bertram, T. H., Wooldridge, P. J., Fried, A., Heikes, B. G., Dibb, J., Crounse, J. D., Wennberg, P. O., Blake, N. J., Blake, D. R., Brune, W. H., Singh, H. B., and Cohen, R. C.: Airborne observations of total $\mathrm{RONO}_{2}$ : new constraints on the yield and lifetime of isoprene nitrates, Atmos. Chem. Phys., 9, 14511463, doi:10.5194/acp-9-1451-2009, 2009.

Perring, A. E., Pusede, S. E., and Cohen, R. C.: An observational perspective on the atmospheric impacts of alkyl and multifunctional nitrates on ozone and secondary organic aerosol, Chem. Rev., 113, 5848-5870, doi:10.1021/cr300520x, 2013.

Pleim, J. E., Bash, J. O., Walker, J. T., and Cooter, E. J.: Development and evaluation of an ammonia bidirectional flux parameterization for air quality models, J. Geophys. Res.-Atmos., 118, 3794-3806, doi:10.1002/jgrd.50262, 2013.

Presto, A. A., Huff Hartz, K. E., and Donahue, N. M.: Secondary organic aerosol production from terpene ozonolysis. 2. Effect of $\mathrm{NO}_{x}$ concentration, Environ. Sci. Technol., 39 7046-7054, doi:10.1021/es050400s, 2005.

Pusede, S. E. and Cohen, R. C.: On the observed response of ozone to $\mathrm{NO}_{x}$ and VOC reactivity reductions in San Joaquin Valley California 1995-present, Atmos. Chem. Phys., 12, 8323-8339, doi:10.5194/acp-12-8323-2012, 2012.

Pusede, S. E., Gentner, D. R., Wooldridge, P. J., Browne, E. C., Rollins, A. W., Min, K.-E., Russell, A. R., Thomas, J., Zhang, L., Brune, W. H., Henry, S. B., DiGangi, J. P., Keutsch, F. N., Harrold, S. A., Thornton, J. A., Beaver, M. R., St. Clair, J. M., Wennberg, P. O., Sanders, J., Ren, X., VandenBoer, T. C., Markovic, M. Z., Guha, A., Weber, R., Goldstein, A. H., and Cohen, R. C.: On the temperature dependence of organic reactivity, nitrogen oxides, ozone production, and the impact of emission controls in San Joaquin Valley, California, Atmos. Chem. Phys., 14, 3373-3395, doi:10.5194/acp-14-3373-2014, 2014.

Pusede, S. E., VandenBoer, T. C., Murphy, J. G., Markovic, M. Z., Young, C. J., Veres, P. R., Roberts, J. M., Washenfelder, R. A., Brown, S. S., Ren, X., Tsai, C., Stutz, J., Brune, W. H., Browne, E. C., Wooldridge, P. J., Graham, A. R., Weber, R., Goldstein, A. H., Dusanter, S., Griffith, S. M., Stevens, P. S., Lefer, B. L., and Cohen, R. C.: An atmospheric constraint on the $\mathrm{NO}_{2}$ dependence of daytime near-surface nitrous acid (HONO), Environ. Sci. Technol., 49, 12774-12781, doi:10.1021/acs.est.5b02511, 2015.

Rollins, A. W., Browne, E. C., Min, K.-E., Pusede, S. E., Wooldridge, P. J., Gentner, D., Goldstein, A. H., Liu, S., Day, D. A., Russell, L. M., and Cohen, R. C.: Evidence for $\mathrm{NO}_{x}$ control over nighttime SOA formation, Science, 337, 1210-1212, doi:10.1126/science.1221520, 2012.

Rood, M. J., Shaw, M. A., Larson, T. V., and Covert, D. S.: Ubiquitous nature of ambient metastable aerosol, Nature, 337, 537-539, doi:10.1038/337537a0, 1989.

Russell, A. R., Valin, L. C., Bucsela, E. J., Wenig, M. O., and Cohen, R. C.: Space-based constraints on spatial and temporal patterns of $\mathrm{NO}_{x}$ emissions in California, 2005-2008, Environ. Sci. Technol., 44, 3608-3615, doi:10.1021/es903451j, 2010.

Russell, A. R., Perring, A. E., Valin, L. C., Bucsela, E. J., Browne, E. C., Wooldridge, P. J., and Cohen, R. C.: A high spatial resolution retrieval of $\mathrm{NO}_{2}$ column densities from OMI: method and evaluation, Atmos. Chem. Phys., 11, 8543-8554, doi:10.5194/acp-11-8543-2011, 2011. 
Russell, A. R., Valin, L. C., and Cohen, R. C.: Trends in $\mathrm{OMI} \mathrm{NO}_{2}$ observations over the United States: effects of emission control technology and the economic recession, Atmos. Chem. Phys., 12, 12197-12209, doi:10.5194/acp-12-12197-2012, 2012.

San Joaquin Valley Air Pollution Control Board, Rule 4901Wood burning fireplaces and wood burning heaters: http://www. valleyair.org/rules/currntrules/r4901.pdf (last access: 5 January 2016), 2003.

Schiferl, L. D., Heald, C. L., Nowak, J. B., Holloway, J. S., Neuman, J. A., Bahreini, R., Pollack, I. B., Ryerson, T. B., Wiedinmyer, C., and Murphy, J. G.: An investigation of ammonia and inorganic particulate matter in California during the CalNex campaign, J. Geophys. Res.-Atmos., 119, 1883-1902, doi:10.1002/2013jd020765, 2014.

Sehmel, G. A.: Particle and gas dry deposition: a review, Atmos. Environ., 14, 983-1011, doi:10.1016/0004-6981(80)90031-1, 1980.

Shaw Jr., R. W., Stevens, R. K., Bowermaster, J., Tesch, J. W., and Tew, E.: Measurements of atmospheric nitrate and nitric acid: the denuder difference experiment, Atmos. Environ., 16, 845-853, doi:10.1016/0004-6981(82)90403-6, 1982.

Shaw, S. L., Mitloehner, F. M., Jackson, W., Depeters, E. J., Fadel, J. G., Robinson, P. H., Holzinger, R., and Goldstein, A. H.: Volatile organic compound emissions from dairy cows and their waste as measured by proton-transfer-reaction mass spectrometry, Environ. Sci. Technol., 41, 1310-1316, doi:10.1021/es061475e, 2007.

Sievering, H., Kelly, T., McConville, G., Seibold, C., and Turnipseed, A.: Nitric acid dry deposition to conifer forests: Niwot Ridge spruce-fir-pine study, Atmos. Environ., 35, 38513859, doi:10.1016/S1352-2310(01)00156-X, 2001.

Slinn, W. G. N.: Predictions for particle deposition to vegetative canopies, Atmos. Environ., 16, 1785-1794, doi:10.1016/00046981(82)90271-2, 1982.

Smith, T. B., Lehrman, D. E., Reible, D. D., and Shair, F. H.: The origin and fate of airborne pollutants within the San Joaquin Valley - volume 1, California Air Resources Board, Sacramento, California, 19 pp., 1981.

Stolzenburg, M. R., Dutcher, D. D., Kirby, B. W., and Hering, S. V.: Automated measurement of the size and concentration of airborne particulate nitrate, Aerosol Sci. Technol., 37, 537-546, doi:10.1080/02786820300922, 2003.

Stull, R. B.: An Introduction to Boundary Layer Meteorology, 1st Edition, Atmospheric and Oceanographic Sciences Library, 13, Springer, the Netherlands, 1988.

Stutz, J., Alicke, B., Ackermann, R., Geyer, A., Wang, S. H., White, A. B., Williams, E. J., Spicer, C. W., and Fast, J. D.: Relative humidity dependence of HONO chemistry in urban areas, J. Geophys. Res.-Atmos., 109, D03307, doi:10.1029/2003jd004135, 2004.

Thornton, J. A., Wooldridge, P. J., and Cohen, R. C.: Atmospheric $\mathrm{NO}_{2}$ : in situ laser-induced fluorescence detection at parts per trillion mixing ratios, Anal. Chem., 72, 528-539, doi:10.1021/ac9908905, 1999.

Thornton, J. A., Braban, C. F., and Abbatt, J. P. D.: $\mathrm{N}_{2} \mathrm{O}_{5}$ hydrolysis on sub-micron organic aerosols: the effect of relative humidity, particle phase, and particle size, Phys. Chem. Chem. Phys., 5, 4593-4603, doi:10.1039/b307498f, 2003.
Vayenas, D. V., Takahama, S., Davidson, C. I., and Pandis, S. N.: Simulation of the thermodynamics and removal processes in the sulfate-ammonia-nitric acid system during winter: implications for $\mathrm{PM}_{2.5}$ control strategies, J. Geophys. Res.-Atmos., 110, D07S14, doi:10.1029/2004JD005038, 2005.

Volpe Horii, C., William Munger, J., Wofsy, S. C., Zahniser, M., Nelson, D., and Barry McManus, J.: Atmospheric reactive nitrogen concentration and flux budgets at a Northeastern U.S. forest site, Agr. Forest Meteorol., 133, 210-225, doi:10.1016/j.agrformet.2004.08.009, 2005.

Wagner, N. L., Riedel, T. P., Young, C. J., Bahreini, R., Brock, C. A., Dube, W. P., Kim, S., Middlebrook, A. M., Ozturk, F., Roberts, J. M., Russo, R., Sive, B., Swarthout, R., Thornton, J. A., VandenBoer, T. C., Zhou, Y., and Brown, S. S.: $\mathrm{N}_{2} \mathrm{O}_{5}$ uptake coefficients and nocturnal $\mathrm{NO}_{2}$ removal rates determined from ambient wintertime measurements, J. Geophys. Res.-Atmos., 118, 9331-9350, doi:10.1002/jgrd.50653, 2013.

Wahner, A., Mentel, T. F., Sohn, M., and Stier, J.: Heterogeneous reaction of $\mathrm{N}_{2} \mathrm{O}_{5}$ on sodium nitrate aerosol, J. Geophys. Res.Atmos., 103, 31103-31112, doi:10.1029/1998JD100022, 1998.

Waldman, J. M., Munger, J. W., Jacob, D. J., Flagan, R. C., Morgan, J. J., and Hoffmann, M. R.: Chemical-composition of acid fog, Science, 218, 677-680, doi:10.1126/science.218.4573.677, 1982.

Walker, J. M., Philip, S., Martin, R. V., and Seinfeld, J. H.: Simulation of nitrate, sulfate, and ammonium aerosols over the United States, Atmos. Chem. Phys., 12, 11213-11227, doi:10.5194/acp12-11213-2012, 2012.

Watson, J. G., Chow, J. C., Bowen, J. L., Lowenthal, D. H., Hering, S., Ouchida, P., and Oslund, W.: Air quality measurements from the Fresno Supersite, J. Air Waste Ma., 50, 1321-1334, doi:10.1080/10473289.2000.10464184, 2000.

Weibring, P., Richter, D., Fried, A., Walega, J. G., and Dyroff, C.: Ultra-high-precision mid-IR spectrometer II: system description and spectroscopic performance, Appl. Phys. B, 85, 207-218, doi:10.1007/s00340-006-2300-4, 2006.

Weibring, P., Richter, D., Walega, J. G., and Fried, A.: First demonstration of a high performance difference frequency spectrometer on airborne platforms, Opt. Express, 15, 13476-13495, doi:10.1364/OE.15.013476, 2007.

Williams, E. J., Baumann, K., Roberts, J. M., Bertman, S. B., Norton, R. B., Fehsenfeld, F. C., Springston, S. R., Nunnermacker, L. J., Newman, L., Olszyna, K., Meagher, J., Hartsell, B., Edgerton, E., Pearson, J. R., and Rodgers, M. O.: Intercomparison of ground-based $\mathrm{NO}_{y}$ measurement techniques, J. Geophys. Res.Atmos., 103, 22261-22280, doi:10.1029/98JD00074, 1998.

Winer, A. M., Peters, J. W., Smith, J. P., and Pitts, J. N.: Response of commercial chemiluminescent nitric oxide-nitrogen dioxide analyzers to other nitrogen-containing compounds, Environ. Sci. Technol., 8, 1118-1121, doi:10.1021/es60098a004, 1974.

Wooldridge, P. J., Perring, A. E., Bertram, T. H., Flocke, F. M., Roberts, J. M., Singh, H. B., Huey, L. G., Thornton, J. A., Wolfe, G. M., Murphy, J. G., Fry, J. L., Rollins, A. W., LaFranchi, B. W., and Cohen, R. C.: Total Peroxy Nitrates ( $\Sigma$ PNs) in the atmosphere: the Thermal Dissociation-Laser Induced Fluorescence (TD-LIF) technique and comparisons to speciated PAN measurements, Atmos. Meas. Tech., 3, 593-607, doi:10.5194/amt-3-5932010, 2010. 
Young, D. E., Kim, H., Parworth, C., Zhou, S., Zhang, X., Cappa, C. D., Seco, R., Kim, S., and Zhang, Q.: Influences of emission sources and meteorology on aerosol chemistry in a polluted urban environment: results from DISCOVER-AQ California, Atmos. Chem. Phys. Discuss., 15, 35057-35115, doi:10.5194/acpd-15-35057-2015, 2015.

Zhang, J., Chameides, W. L., Weber, R., Cass, G., Orsini, D., Edgerton, E., Jongejan, P., and Slanina, J.: An evaluation of the thermodynamic equilibrium assumption for fine particulate composition: nitrate and ammonium during the 1999 Atlanta Supersite Experiment, J. Geophys. Res., 108, 8414, doi:10.1029/2001JD001592, 2003.
Zhang, Y., Liu, P., Liu, X.-H., Pun, B., Seigneur, C., Jacobson, M. Z., and Wang, W.-X.: Fine scale modeling of wintertime aerosol mass, number, and size distributions in central California, J. Geophys. Res.-Atmos., 115, D15207, doi:10.1029/2009jd012950, 2010. 